\title{
What we talk about when we talk about Jerusalem: The duty of non-recognition and the prospects for peace after the US embassy's relocation to the Holy City
}

\author{
Marco Pertile* and Sondra Faccio \\ Facoltà di Giurisprudenza, Università degli Studi di Trento - Via Verdi, 53 - 38122 Trento, Italy, Email: marco.pertile@unitn.it \\ and Scuola di Studi internazionali, Università degli Studi di Trento - Via Gar, 14 - 38122 Trento, Italy, Email: sondra.faccio@ \\ unitn.it
}

\begin{abstract}
The article addresses the legality of the relocation of the United States embassy from Tel Aviv to Jerusalem in light of the duty of non-recognition and the international consensus on the two-state solution. Analysing the massive reaction of states to the United States administration's decision, the article takes stock of the practice on the status of Jerusalem and on the Israeli-Palestinian issue more broadly. The authors conclude that the almost unanimous negative reaction of states and their commitment to the two-state solution will remain a dead letter if the solution to the crisis is left to a future bilateral agreement.
\end{abstract}

Keywords: duty of non-recognition; Jerusalem; self-determination; two-state solution; US embassy

\section{The significance of an embassy in Jerusalem for the Israeli-Palestinian question}

At least since the times of President Carter, all of the United States (US) presidents have qualified the Israeli-Palestinian issue as one of the top priorities of their foreign policy. To a large extent, the degree of success of American administrations in the realm of international relations has thus been measured by referring to their achievements in the Middle East.

Until 2016, an overall assessment of the US position throughout the years revealed a shift towards the protection of the interests of Israel. In particular, the qualification of the Israeli settlements in the Occupied Palestinian Territories (OPT) as illegal had become less firm in time as ambiguous political statements by the Reagan administration substituted the initial condemnation of the Carter administration. ${ }^{1}$ A major turning point in American foreign policy took place in 2004, when the Bush administration departed from the long-standing international consensus that Israel has to withdraw from the

\footnotetext{
${ }^{\star}$ The present article was conceived and written at the School of International Studies of the University of Trento in the context of the research project 'The EU Trade Policy in Civil Wars and Other Cases of Contested Sovereignty: An International Law Perspective'. Marco Pertile and Sondra Faccio have jointly conducted the research at the basis of this article, but its single sections have been authored as follows: Sondra Faccio is the author of sections 2, 3, 5.1.3, 5.1.4, 5.2.1; Marco Pertile is the author of sections 1, 5.1.1,5.1.2, 5.2.2, 5.2.3. Sections 4 and 6 were written jointly. The authors are grateful to Tarcisio Gazzini, Giuseppe Nesi, Nicola Nesi, Antonello Tancredi, and the two anonymous reviewers for comments on earlier versions of the manuscript that greatly improved its content. The usual disclaimer obviously applies. Finally, the reader should be aware that the article was approved for publication in its last version on 21 November 2019, before US President Donald Trump released his administration's peace plan for the Middle East, early in 2020. The authors, therefore, could not consider the content of such a plan and the international reactions to it.

${ }^{1}$ See S. Anziska, Preventing Palestine: A Political History from Camp David to Oslo (2018), 177-8. 
territories occupied in 1967, admitting that 'new realities on the ground, including already existing major Israeli populations [sic] centres' had to be taken into account. ${ }^{2}$ However, in 2016, the pendulum swung in the opposite direction when President Obama's administration abstained on United Nations Security Council (UNSC) Resolution 2334, which reaffirmed 'that the establishment by Israel of settlements in the Palestinian territory occupied since 1967, including East Jerusalem, has no legal validity and constitutes a flagrant violation under international law' and underlined that 'any changes to the 4 June 1967 lines, including with regard to Jerusalem, other than those agreed by the parties through negotiations' will not be recognized. ${ }^{3}$ The resolution also implied an indirect, but clear, reference to the obligation of non-recognition, calling upon member states 'to distinguish, in their relevant dealings, between the territory of the State of Israel and the territories occupied since 1967'.

Against this background, President Trump inaugurated his mandate with another u-turn. Without putting forward a comprehensive peace plan, ${ }^{4}$ on 6 December 2017, he announced that the US would move its diplomatic mission to the State of Israel from Tel Aviv to Jerusalem, implementing a 1995 decision of Congress for which past US presidents had constantly exercised their presidential waiver. Within the international community, the move was widely seen as departing from the well-established international consensus that traditionally considers Jerusalem as a final status issue, to be decided through negotiation by the parties within the framework of the applicable UN resolutions.

So far, only Guatemala has decided to follow the example of the US ${ }^{5}$ while few other states, notably the Czech Republic, ${ }^{6}$ Romania, ${ }^{7}$ Honduras, ${ }^{8}$ and Australia, ${ }^{9}$ have advanced proposals to relocate their diplomatic mission to Jerusalem. The Palestinian leadership, however, has made it clear that they will not accept any mediation led by the US in the future. ${ }^{10}$ Demonstrations in the West Bank and Gaza were violently repressed by the Israeli authorities and a draft UNSC resolution condemning the relocation of the embassy forced the US to make use of its veto power before the UNSC. Subsequently, the UN General Assembly (UNGA) adopted a similar text with the favourable vote of 128 states, 35 abstentions, and 9 votes against, including the US. ${ }^{11}$ Overall, the contentious nature of the decision revitalized the debate on the Israeli-Palestinian question and prompted the reaction of virtually all of the states of the international community, which took position on several occasions before the UNGA, the UNSC and elsewhere.

We believe that this massive reaction by states allows a unique opportunity for taking stock of states' practice on the status of Jerusalem and on the Israeli-Palestinian issue more broadly. Furthermore, for the first time, the focus of the global debate is on the behaviour of a third state,

\footnotetext{
${ }^{2}$ The statement is available at $\mathrm{mfa}$.gov.il/mfa/foreignpolicy/peace/mfadocuments/pages/exchange $\% 20 \mathrm{of} \% 20 \mathrm{letters} \%$ 20sharon-bush\%2014-apr-2004.aspx.

${ }^{3}$ UNSC, Res. 2334, UN Doc. S/RES/2334 (2016).

${ }^{4}$ The economic part of a peace plan, which seems to abandon the two-state solution, was put forward only in June 2019. See P. R. Pillar, 'The Kushner Plan: Keeping the Israeli-Palestinian Peace Out of Reach', (2019) XVIII (4) Journal of Palestine Studies 113.

${ }^{5 ‘}$ Guatemala retornó la sede de su Embajada en Israel a la ciudad de Jerusalén’, 16 May 2018, available at www.minex.gob.gt/ noticias/Noticia.aspx?ID $=27770$.

${ }^{6}$ Joint Statement of the Highest Constitutional Officials of the Czech Republic on Foreign Policy, 12 September 2018, available at www.hrad.cz/en/for-media/press-releases/joint-statement-of-the-highest-constitutional-officials-of-the-czechrepublic-on-foreign-policy-14250.

7‘Prime Minister Viorica Dancila’s visit to the State of Israel', 25 April 2018, available at gov.ro/en/news/prime-ministerviorica-dancila-s-visit-to-the-state-of-israel\&page $=1$.

${ }^{8 ‘}$ Israel Welcome the Honduras Decision to Move its Embassy to Jerusalem', 13 April 2018, available at mfa.gov.il/MFA/ PressRoom/2018/Pages/Honduran-embassy-to-move-to-Jerusalem-13-April-2018.aspx.

9'Statement to the House of Representatives on the 70th Anniversary of Diplomatic Relations with Israel', 19 February 2019, available at www.pm.gov.au/media/statement-house-representatives-70th-anniversary-diplomatic-relations-israel.

${ }^{10}$ UNSC, The situation in the Middle East, including the Palestinian question, UN Doc. S/PV.8128 (2017), at 2. Palestinian President Abbas condemned the move and stressed that 'the United States had withdrawn from its role as a mediator in the peace process'.

${ }^{11}$ UNGA, Res. ES-10/19, UN Doc. A/RES/ES-10/19 (2017).
} 
notably the US, towards the Israeli-Palestinian issue, rather than on the Israeli-Palestinian issue itself and this puts at the forefront the widely debated obligation of non-recognition of unlawful territorial situations. The question of the status of Jerusalem is crucial because of its connection to the final borders of the two states: the latter depends on the agreement on Jerusalem and, vice versa, any decision on the borders affects the status of Jerusalem and, consequently, the prospects for peace in the region. ${ }^{12}$ Indeed, as Henry Cattan said in 1985:

[t]he problem of Jerusalem is one of the most emotional and explosive issues in the world ... its importance and dimensions transcend the Middle East and its people .... It is the spiritual and religious heritage of one-half of humanity and is holy for one thousand of million Christians, seven hundred million Muslims, and fourteen million Jews. ${ }^{13}$

Despite its uniqueness, however, Jerusalem remains, at least in part, an occupied territory and as the rest of the Palestinian territory has been the object of a settlement policy which is likely to have a substantial impact on the final status of the city.

In light of the above, the present article aims to answer, through a comprehensive analysis of the practice, two key questions emerging from the latest developments: first, whether there is room for an obligation of non-recognition in the Israeli-Palestinian question and what that implies and, second, what the prospects for peace are. After recalling the main UNSC and GA resolutions on the status of Jerusalem and the Israeli-Palestinian question (Section 2) and the US position on the matter (Section 3), the article will address these two questions through a systematic analysis of states' practice. Section 4 will present the results of our investigation. Section 5 will highlight our main findings on the research questions, which are then summarized in our concluding remarks (Section 6). With a view to ensuring full disclosure of the primary sources upon which our conclusions are based, a compilation of all of the examined statements has been made available on the Internet as an annex to this article. ${ }^{14}$

\section{Jerusalem and the Israeli-Palestinian question at the UN: A review of the relevant resolutions}

The Israeli-Palestinian question has marked the activities of the UN since its inception and represents by far the most debated issue within the organization. At the heart of it is Jerusalem as ' $\mathrm{t}$ ] here will never be a lasting settlement of the Israeli-Palestinian conflict without a solution to the status of Jerusalem acceptable both to most Israelis and to most Palestinians' ${ }^{15}$

Numerous resolutions have been adopted by the UNGA and the UNSC contributing to the development of an international consensus on the matter, based on the international law principles of self-determination and the inadmissibility of the acquisition of territory by force. ${ }^{16}$ States have significantly referred to the UNSC and GA resolutions in their foreign policy statements, ${ }^{17}$ including within the UN Educational, Scientific, Cultural Organization (UNESCO). ${ }^{18}$

\footnotetext{
${ }^{12}$ J. V. Whitbeck, 'The Road to Peace Starts in Jerusalem: the “Condominium” Solution', (1996) 45(3) Catholic University Law Review 781.

${ }^{13}$ H. Cattan, 'The Question of Jerusalem', (1985) 7(2/3) Arab Studies Quarterly 131, at 131.

${ }^{14}$ The Annex is available at www.sis.unitn.it/1380/the-eu-trade-policy-in-civil-wars-and-other-cases-of-contestedsovereignty-an-international-law; unitn.academia.edu/MarcoPertile.

${ }^{15}$ See Whitbeck, supra note 12 , at 781 .

${ }^{16}$ Ex multis, UNGA, UN Doc. A/RES/3376 (1975); UNSC, UN Doc. S/RES/242 (1967); UN Doc. S/RES/476 (1980), UN Doc. S/RES/478 (1980); and UN Doc. S/RES/2334 (2016).

${ }^{17}$ See Section 5 , infra.

${ }^{18}$ Decision 29 COM 7A.31 (2005), available at whc.unesco.org/en/decisions/350/; Decision 41 COM 7A.36 (2017), available at whc.unesco.org/en/decisions/6982/.
} 
As is well known, the UN took up the question of Palestine in $1947 .{ }^{19}$ From the British occupation of Ottoman Palestine in 1917 until the end of the British mandate, a number of conflicting claims had been put forward with respect to the status of Jerusalem and the Holy Places. Also for this reason, when the first resolution on Palestine (UNGA Resolution 181 (II) of 1947) provided for the termination of the mandate and the partition of Palestine into a Jewish State and an Arab State, the City of Jerusalem should have become a corpus separatum under a special international regime administered by the $\mathrm{UN}{ }^{20}$ This is the starting point established by the United Nations: neither the Jewish State nor the Arab one would have had exclusive sovereignty over Jerusalem. Tensions between Arabs and Israelis, however, escalated into the First Middle East War, which ended in 1949 with armistice agreements granting control over the Gaza Strip and the West Bank to Egypt and Jordan respectively. In the aftermath of the 1967 Six-Day War leading to the occupation by Israel of the West Bank, East Jerusalem, the Gaza Strip, and the Syrian Golan Heights, UNSC Resolution 242 was adopted unanimously 'emphasizing the inadmissibility of the acquisition of territory by war' and requiring the 'withdrawal of Israel armed forces from territories occupied' during the conflict. The resolution also emphasized the 'respect for and acknowledgment of the sovereignty, territorial integrity and political independence of every state in the area and their right to live in peace within secure and recognized boundaries' ${ }^{21}$ Resolutions 2253 and 2254, adopted by the UNGA in 1967, also condemned the 'invalid' measures adopted by Israel to change the status of Jerusalem and 'call[ed] upon Israel to rescind all measures already taken and to desist forthwith to take any action which would alter the status of Jerusalem'. ${ }^{22}$ These resolutions made clear that the UN would not have recognized any changes to the city's status. Since then the position of the organization has not changed: no state has sovereignty over Jerusalem. ${ }^{23}$

Since 1967, Israeli governments have implemented the policy of settlements whose expansion continued steadily during the occupation. ${ }^{24}$ As a result, the UNGA, ${ }^{25}$ the $\mathrm{UNSC}^{26}$ and the ICJ ${ }^{27}$

\footnotetext{
${ }^{19}$ Division for Palestinian Rights (DPR), The Origins and Evolution of the Palestine Problem: 1917-1977, UN Doc. ST/SG/ ser. F/1. (1979), available at unispal.un.org/DPA/DPR/unispal.nsf/9a798adbf322aff38525617b006d88d7/d442111e70e417e 3802564740045a309? OpenDocument\#In\%20favour\%3A\%20Australia\%2C\%20Belgium\%2C\%20B.

${ }^{20}$ UNGA, Res. A/RES/181(II), UN Doc. A/RES/181(II) (1947). On 15 May 1948, the newly formed State of Israel declared it was ready to co-operate with the UN to implement Resolution 181(II) and the partition plan. See UN Doc. S/747; A. Cassese, 'Legal Considerations on the International Status of Jerusalem', in A. Cassese, P. Gaeta and S. Zappalà (eds.), The Human Dimension of International Law: Selected Papers of Antonio Cassese (2012), 276; V. Kattan, 'Why U.S. Recognition of Jerusalem Could Be Contrary to International Law', (2018) XLVII (3) Journal of Palestine Studies 79.

${ }^{21}$ UNSC, Res. 242, UN Doc. S/RES/242 (1967).

${ }^{22}$ UNGA, Res. 2253, UN Doc. A/RES/2253 (ES-V) (1967); Res. 2254, UN Doc. A/RES/2254 (ES-V) (1967).

${ }^{23}$ UNSC, The situation in the Middle East, including the Palestinian question, UN Doc. S/PV 8138 (2017), at 4-5. See J. Dugard, Recognition and the United Nations (1987), at 111.

${ }^{24}$ Human Rights Council, Report of the Human Rights Council on its thirty-fourth session, UN Doc. A/HRC/34/2 (2017), available at www.ohchr.org/en/hrbodies/hrc/regularsessions/session34/pages/34regularsession.aspx; see DPR, supra note 19.

${ }^{25}$ See, among others, UNGA, Res. 71/97, UN Doc. A/RES/71/97 (2016); Res. 68/82, UN Doc. A/RES/68/82 (2013); Res. 65/ 104, UN Doc. A/RES/65/104 (2010); Res. 63/97, UN Doc. A/RES/63/97 (2008); Res. 62/108, UN Doc. A/RES/62/108 (2007); Res. 61/118, UN Doc. A/RES/61/118 (2006); Res. 60/106, UN Doc. A/RES/60/106 (2005); Res. 59/123, UN Doc. A/RES/59/123 (2004); Res. 57/126, UN Doc. A/RES/57/126 (2002); Res. 56/61, UN Doc. A/RES/56/61 (2001); Res. 54/78, UN Doc. A/RES/ 54/78 (1999), 'an obstacle to the peace'; Res. 52/66, UN Doc. A/RES/52/66 (1997), 'an obstacle to peace and economic and social development'; Res. ES-10/3, UN Doc. A/RES/ES-10/3 (1997); Res. 50/129, UN Doc. A/RES/50/129 (1995); Res. 49/132, UN Doc. A/RES/49/132 (1994); Res. 48/212, UN Doc. A/RES/48/212 (1993); Res. 47/172, UN Doc. A/RES/47/172 (1992); Res. 46/199, UN Doc. A/RES/46/199 (1991).

${ }^{26}$ UNSC Res. 2334, UN Doc. S/RES/2334 (2016); Res. 465, UN Doc. S/RES/465 (1980); Res. 446, UN Doc. S/RES/446 (1979); Res. 452, UN Doc. S/RES/452 (1979).

${ }^{27}$ Legal Consequences of the Construction of a Wall in the Occupied Palestinian Territory, Advisory Opinion, 9 June 2004, [2004] ICJ Rep. 136.
} 
have consistently affirmed that the settlements in the OPT, including East Jerusalem, are 'illegal' and/or 'an obstacle to the peace'. In June 1980, Israel adopted the 'Basic Law: Jerusalem Capital of Israel' declaring Jerusalem, complete and united, as the capital of Israel. ${ }^{28}$ States within the UNSC reacted by adopting Resolutions 476 and 478. With Resolution 476, the UNSC reaffirmed 'the overriding necessity to end the prolonged occupation of Arab territories occupied by Israel since 1967, including Jerusalem', and condemned Israel's attempt to change the character and status of the Holy City of Jerusalem, stating that all 'measures which have altered the geographic, demographic and historical character and status of the Holy City of Jerusalem are null and void and must be rescinded in compliance with the relevant resolutions of the Security Council'. ${ }^{29}$ With Resolution 478, the UNSC decided "not to recognize the "basic law" and such other actions by Israel that ... seek to alter the character and status of Jerusalem' and called upon all member states to withdraw their missions from the Holy City. ${ }^{30}$ Resolutions 476 and 478 were adopted with the abstention of the US. ${ }^{31}$

The crucial issue of the settlements came to the surface again before the UNSC in December 2003, when the Council endorsed unanimously the Middle East Quartet's Road Map principles, including: the freezing of 'all settlement activity (including natural growth of settlements)'. ${ }^{32}$ Meanwhile the number of states recognizing Palestine as a state had grown considerably and, with Resolution 67/19 of 2012, the UNGA granted Palestine non-member observer state status reaffirming 'the right of the Palestinian people to self-determination and to independence in their State of Palestine on the Palestinian territory occupied since 1967'.33 On 23 December 2016, Resolution 2334 was adopted, with the sole abstention of the US, ${ }^{34}$ and reaffirmed that settlements in the OPT represent a violation of international law, reiterating that the UN will not recognize any changes to the 4 June 1967 lines, including in Jerusalem, other than those agreed by the parties. ${ }^{35}$ After President Trump's speech of 6 December, the US vetoed a draft resolution affirming 'that any decisions and actions which purport to have altered, the character, status or demographic composition of the Holy City of Jerusalem have no legal effect, are null and void and must be rescinded in compliance with relevant resolutions', calling upon all states 'to refrain from the establishment of diplomatic missions in the Holy City of Jerusalem, pursuant to Resolution 478 (1980) of the Security Council' and demanding that all states 'comply with Security Council resolutions regarding the Holy City of Jerusalem, and not to recognize any actions or measures contrary to those resolutions' ${ }^{36}$ However, the UNGA subsequently adopted - with 128 votes in favour, nine votes against, 35 abstentions, and 21 absences - Resolution 10/19, which mirrors the content of such draft UNSC resolution and reiterates the long-standing position of the organ on the illegality of any measure aimed at unilaterally changing the status of Jerusalem. ${ }^{37}$

\footnotetext{
${ }^{28}$ Basic Law: Jerusalem Capital of Israel, passed by the Knesset on the 17th Av, 5740 (30 July 1980) (Unofficial translation), available at www.knesset.gov.il/laws/special/eng/basic10_eng.htm.

${ }^{29}$ UNSC, Res. 476, UN. Doc. S/RES/476 (1980).

${ }^{30}$ UNSC, Res. 478, UN. Doc. S/RES/478 (1980).

${ }^{31}$ UNSC, The Situation in the Middle East: Letter dated 28 May 1980 from the Acting Permanent Representative of Pakistan to the United Nations addressed to the President of the Security Council (S/13966), UN Doc. S/PV.2242 (1980), at 2-3.

${ }^{32}$ UNSC, Res. 1515, UN Doc. S/RES/1515 (2003); Letter dated 7 May 2003 from the Secretary-General addressed to the President of the Security Council, UN Doc. S/2003/529 (2003).

${ }^{33}$ On Palestine's statehood see Y. Ronen, 'Recognition of the State of Palestine - Still too Much too Soon?', in C. Chinkin and F. Baetens (eds.), Sovereignty, Statehood and State Responsibility (2015), 229; J. Quigley, The Statehood of Palestine (2010).

${ }^{34}$ UNSC, The situation in the Middle East, including the Palestinian question, UN Doc. S/PV.7853 (2016).

${ }^{35}$ UNSC, Res. 2334, UN Doc. S/RES/2334 (2016).

${ }^{36}$ UNSC, Egypt: draft resolution, UN Doc. S/2017/1060 (2017).

${ }^{37}$ UNGA, Res. ES-10/19, UN Doc. A/RES/ES-10/19 (2017).
} 


\section{From the Jerusalem Embassy Act to the relocation of the embassy: The position of the United States}

The position of the US concerning Jerusalem has evolved over the years and can be said to have gone through at least three different phases: first, the phase of the 'international' solution, according to which the US refused to recognize Israeli sovereignty over Jerusalem and pushed for the internationalization of the city; second, the phase of the 'negotiated' solution; and, eventually, the phase of the recognition of Israeli sovereignty over Jerusalem, with a negotiated solution concerning the geographical boundaries of such sovereignty. ${ }^{38}$

In the 1940s, during the first phase, the position of the US reflected the above-mentioned UNGA Resolutions of 1947 and 1948 according to which Jerusalem should have been a separate area from the rest of Palestine and member states would not have recognized any state's sovereignty over this area. ${ }^{39}$ According to the US Secretary of State, at that time the US could not '.. support any arrangements which would purport to authorize estab [sic] of Israeli or TJ sovereignty over parts of Jerusalem area', ${ }^{40}$

Progressively, the US realized that plans to internationalize Jerusalem were not feasible and started to favour a negotiated resolution of the issue. ${ }^{41}$ This emerges in 1949 when the US Secretary of State, Dean Acheman, conceded in a memorandum to President Truman that 'any solution agreed upon by the Christian World and by Israel and Jordan could be supported by us'. ${ }^{42}$

In 1967 - when Israel occupied the West Bank, including East Jerusalem, and the Gaza Strip along with the Egyptian Sinai Peninsula, and the Syrian Golan Heights - the US Department of State stressed again US opposition 'to any unilateral efforts to change the permanent position in Jerusalem' and its inability to 'recognize Israeli measures as having effected changes in formal status of Jerusalem'. ${ }^{43}$ The US refused to recognize the unified municipal administration of Jerusalem as a valid annexation or a permanent change in the legal status of Jerusalem and expressed its intention to "work toward equitable settlement of Jerusalem problem developed through consultation among all concerned'. ${ }^{44}$

\footnotetext{
${ }^{38}$ The Acting Secretary of State to the Consulate General in Jerusalem, 'Foreign Relations of the United States, 1949, The Near East, South Asia, and Africa, Volume VI' (501.BB Palestine/1-1849: Telegram), available at history.state.gov/ historicaldocuments/frus1949v06/d409; The Secretary of State to the Embassy in Israel, Foreign Relations of the United States, 1949, The Near East, South Asia, and Africa, Volume VI (501.BB Palestine/12-1749: Telegram), available at history.state.gov/historicaldocuments/frus1949v06/d1084; Secretary of State to the President, Foreign Relations of the United States, 1949, The Near East, South Asia, and Africa, Volume VI, Document 1083 (501.BB Palestine/12-2049: Memorandum), available at history.state.gov/historicaldocuments/frus1949v06/d1083; Circular Telegram From the Department of State to All Posts, Foreign Relations of the United States, 1964-1968, Arab-Israeli Crisis and War, 1967, Volume XIX (Jerusalem Resolution in UNGA: Circular Telegram), available at history.state.gov/historicaldocuments/ frus1964-68v19/d344; Secretary of State, Jerusalem and the Peace Negotiations (Statement before the UNSC on August 20, 1980), available at babel.hathitrust.org/cgi/pt?id=msu.31293008122339;view=1up;seq=90.

${ }^{39}$ UNGA, Res. 181(II), UN Doc. A/RES/181(II) (1947); Res. 194(III), UN Doc. A/RES/194(III) (1948).

${ }^{40}$ The Acting Secretary of State to the Consulate General in Jerusalem, Foreign Relations of the United States, 1949, The Near East, South Asia, and Africa, Volume VI (501.BB Palestine/1-1849: Telegram), supra note 38. See also, The Secretary of State to the Embassy in Israel, Foreign Relations of the United States, 1949, The Near East, South Asia, and Africa, Volume VI (501.BB Palestine/12-1749: Telegram), supra note 38; Secretary of State, Foreign Relations of the United States, 1949, The Near East, South Asia, and Africa, Volume VI (501.BB Palestine/12-2049: Memorandum to the President), supra note 38.

${ }^{41}$ On 9 December 1949, the UNGA adopted Res. 303(IV) restating its aim that Jerusalem be placed under a permanent international regime. This resolution was strongly opposed by Jordan and Israel. The US abstained arguing that 'it was unrealistic as it could not be implemented by the United Nations against the wishes of Israel and Jordan ...'.

${ }^{42}$ Secretary of State, Foreign Relations of the United States, 1949, The Near East, South Asia, and Africa, Volume VI (501.BB Palestine/12-2049: Memorandum), supra note 38.

${ }^{43}$ Department of State, Foreign Relations of the United States, 1964-1968, Arab-Israeli Crisis and War, 1967, Volume XIX (1508. Subj: Jerusalem Resolution in UNGA: Circular Telegram), supra note 38.

${ }^{44}$ Ibid.
} 
In the following years, the US reiterated this position and in July 1980, after Israel enacted the law on Jerusalem as capital of Israel, argued that the 'question of Jerusalem must be addressed in the context of negotiations for a comprehensive, just and lasting Middle East Peace'. ${ }^{45}$ This position was further confirmed in 2015 by the US Supreme Court's opinion in the well-known Zivotofsky v. Kerry case. ${ }^{46}$

From the 1980s, however, Congress began to propose bills and to take actions calling on the Government to recognize Jerusalem as Israel's capital and move its embassy there. In 1984, the Reagan Administration objected to a bill, arguing that it infringed upon the prerogatives of the President and went 'beyond the proper scope of legislative action' ${ }^{47}$ In 1989, the so-called Helm Amendment authorized the State Department to construct 'two new diplomatic facilities in Israel, Jerusalem, or the West Bank', provided that the two facilities 'equally preserves the ability of the United States to locate its Ambassador or its Consul General at that site'. ${ }^{48}$ In 1995, the Jerusalem Embassy Act, providing for the relocation of the US embassy in Israel to Jerusalem, was enacted. ${ }^{49}$ It relied on a series of 'findings', including the de facto circumstances that:

since 1950, the city of Jerusalem has been the capital of the State of Israel ... The city of Jerusalem is the seat of Israel's President, Parliament, and Supreme Court, and the site of numerous government ministries and social and cultural institutions $\ldots{ }^{50}$

and on the circumstance that since 1967 and for almost 28 consecutive years, 'Jerusalem has been a united city administered by Israel' and that '[t]he United States conducts official meetings and other business in the city of Jerusalem in de facto recognition of its status as the capital of Israel'. ${ }^{51}$

The Act was opposed by President Clinton as well as by the Justice Department which prepared a memorandum arguing that it was unconstitutional as it interfered with the President's power to make decisions pertaining to recognition. ${ }^{52}$ The memorandum did not include any reference to the duty of non-recognition under international law but it was grounded on the need to safeguard the US President's constitutional prerogatives. ${ }^{53}$ As a result, Article 7 - authorizing the President to postpone opening the embassy in Jerusalem by successive six months increments - was added to the Jerusalem Embassy Act.

\footnotetext{
${ }^{45}$ Secretary of State, Jerusalem and the Peace Negotiations (Statement before the UNSC on August 20, 1980), supra note 38; Department of State, Foreign Relations of the United States, 1977-1980, Volume IX, Arab-Israeli Dispute August 1978December 1980 (Telegram From the Department of State to the Embassy in Egypt), at 1316, available at s3.amazonaws. com/static.history.state.gov/frus/frus1977-80v09/pdf/frus1977-80v09.pdf.

${ }^{46}$ Zivotofsky v. Kerry [2015], at 2, 28, available at www.supremecourt.gov/opinions/14pdf/13-628_3dq3.pdf.

${ }^{47}$ Letter for Dante B. Fascell, Chairman, Committee on Foreign affairs, United States House of Representatives, from George P. Shultz, Secretary of State at 2 (13 February 1984), mentioned at 126 of the Memorandum from Walter Dellinger, Assistant Attorney General, U.S. Dept. of Justice to Abner J. Mikva, Counsel to the President (16 May 1995); Bill S.2031 relating to the residence of the American Ambassador to Israel, introduced 31 October 1983, 98th Congress (1983-1984), available at www.congress.gov/bill/98th-congress/senate-bill/2031.

${ }^{48}$ Just after the approval of the Helm Amendment, a Land Lease and Purchase Agreement for the implementation of the 'diplomatic facilities' provided by the Helm Amendment was executed between the US and Israel. See 'The Helms Amendment and the Legislative History', (1989) 5 Palestine Yearbook of International Law 334; W. Khalidi, 'The Ownership of the U.S. Embassy Site in Jerusalem', (2000) 29(4) Journal of Palestine Studies 80, at 82-3.

${ }^{49}$ Jerusalem Embassy Act of 1995, Public Law 104-45-Nov. 8, 1995, available at www.congress.gov/104/plaws/publ45/ PLAW-104publ45.pdf; Memorandum from Walter Dellinger, supra note 47.

${ }^{50}$ Jerusalem Embassy Act, ibid.

${ }^{51}$ Ibid.

${ }^{52}$ See Memorandum from Walter Dellinger, supra note 47; M. Halberstam, 'The Jerusalem Embassy Act', (1995) 19 Fordham Int'l L.J. 1379.

${ }^{53}$ The power of the President to recognize foreign states has been based on Sec. 3, Art. II of the US Constitution, which establishes that the President 'shall receive ambassadors'. See R. Lapidoth, 'Jerusalem', (May 2013) Max Planck Encyclopaedia of Public International Law (on-line ed.), para. 32; Memorandum from Walter Dellinger, supra note 47.
} 
On 6 December 2017, after 23 years, President Donald Trump eventually implemented the 1995 Jerusalem Embassy Act. In his speech of 6 December 2017, he recognized 'Jerusalem as the capital of Israel' but left open the question of the final status of the city 'including the specific boundaries of the Israeli sovereignty in Jerusalem, or the resolution of contested borders' ${ }^{54}$ This caveat, together with US previous practice on the matter, leaves blurred the reach of the policy change. ${ }^{55}$ The US administration grounded its decision on 'fundamental reality' and notably on the circumstance that 'Jerusalem has been the political, cultural and spiritual homeland of the Jewish people for thousands of years'; on the other hand, the US 'took great care not to prejudge final status negotiations in any way, including the specific boundaries of Israeli sovereignty in Jerusalem, which remains a subject to be negotiated only by the parties'. ${ }^{56}$ On 14 May 2018, the US embassy in Jerusalem was inaugurated in the 'no man's land' across the 1948 cease-fire lines. ${ }^{57}$

\section{Mapping the position of the international community}

President Trump concluded his speech of 6 December 2017 forecasting 'disagreement and dissent regarding this announcement'. No truer words were ever spoken. This position gave rise to reactions from almost all states, which ranged from mild political statements to positions based on international law.

We classify the relevant statements in a table (Table 1) presenting the result of our investigation on our two research questions. ${ }^{58}$

On a point of method, it is worth highlighting preliminarily that the classification of the positions of states may pose significant hurdles. A first problem we encountered is how to deal with states that took position both individually and collectively through a regional organization or group. In those cases, we decided to align the position of the individual state to the collective one only when the collective declaration was explicitly acknowledged in the individual statements. We believe that this choice allows us to identify not only the emerging trends in the practice of states but also the nuances of the position of each country. The most difficult aspect, however, is the rationalization of manifest contradictions. A case in point is Kazakhstan whose declarations simultaneously refer, on the one hand, to the opportunity to abide by the 1967 lines with East Jerusalem as the capital of the Palestinian State, ${ }^{59}$ and on the other, call for the resumption of dialogue 'in the bilateral format and without preconditions' ${ }^{60}$ In these cases, we attempted to resolve the outstanding questions by referring to multilateral documents expressly recalled by the state concerned.

\footnotetext{
${ }^{54}$ Statement by President Trump on Jerusalem, 6 December 2017, available at www.whitehouse.gov/briefings-statements/ statement-president-trump-jerusalem/.

${ }^{55}$ S. R. Anderson, 'More Ambiguous that It Seems', Foreign Policy, 11 December 2017, available at foreignpolicy.com/2017/ 12/11/trumps-jerusalem-policy-is-more-ambiguous-than-it-seems.

${ }^{56}$ UNSC, The situation in the Middle East, including the Palestinian question, UN Doc. S/PV.8139 (2017), at 4.

${ }^{57}$ D. Hughes, 'The U.S. Embassy in Jerusalem: Does location matter?', (2018) 50 QIL, Zoom-in 15.

${ }^{58}$ See Table 1 . The word 'statements' refers to documents published by institutional websites of states, international organizations and groupings. We collected ten statements of five international organizations and groupings (African Union, European Union, Organization of Islamic Cooperation, League of Arab States, Non-Aligned Movement), 57 individual statements of states and analysed 11 UNSC and GA verbatims of debates, which include additional statements by groupings of and individual member states. Altogether, we collected the practice of 175 states. Statements before the UN General Assembly and the UN Security Council include the following debates: UNSC, UN Doc. S/PV.8128 (2017), UN Doc. S/PV 8139 (2017), UN Doc. S/PV. 8167 (2018), UN Doc. S/PV 8183 (2018), UN Doc. S/PV 8244 (2018), UN Doc. S/PV 8256 (2018), UN Doc. S/PV 8265 (2018), UN Doc. S/PV 8272 (2018), UN Doc. S/PV 8293 (2018), UN Doc. S/PV 8316 (2018) and UNGA, Meeting Records, UN Doc. A/ES-10/PV.37 (2017). The time of reference spans from 6 December 2017, the day of the US President's declaration on Jerusalem capital of Israel, until August 2018.

${ }^{59}$ Kazakhstan, UNSC, UN Doc. S/PV 8265 (2018).

${ }^{60}$ Kazakhstan, UNSC, UN Doc. S/PV 8128 (2017).
} 
Table 1. The Position of the International Community on the Relocation of the Embassy and the Prospects for Peace

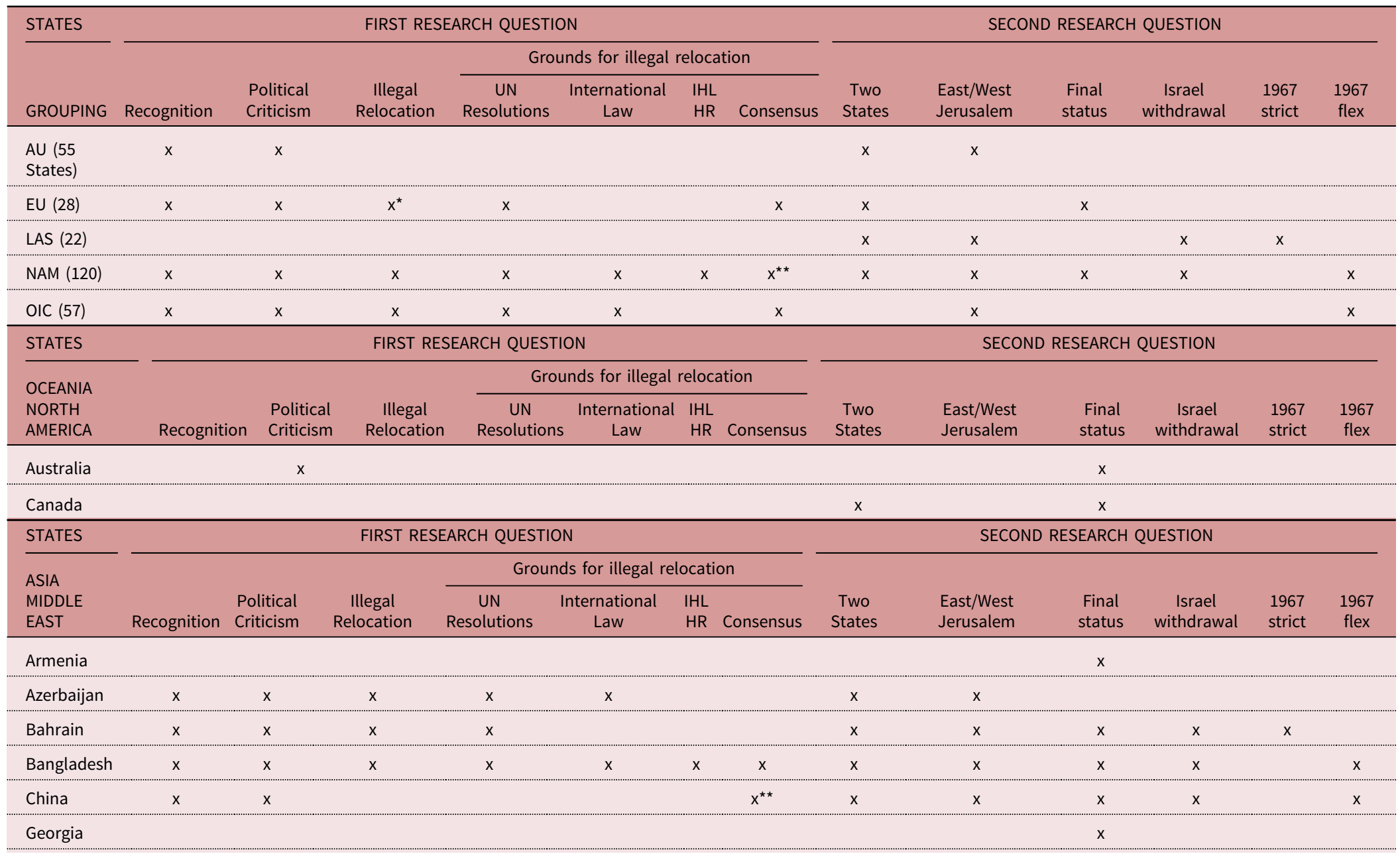


Table 1. (Continued)

\begin{tabular}{|c|c|c|c|c|c|c|c|c|c|c|c|c|c|}
\hline \multirow{3}{*}{$\begin{array}{l}\text { STATES } \\
\text { ASIA } \\
\text { MIDDLE } \\
\text { EAST }\end{array}$} & \multicolumn{7}{|c|}{ FIRST RESEARCH QUESTION } & \multicolumn{6}{|c|}{ SECOND RESEARCH QUESTION } \\
\hline & \multirow[b]{2}{*}{ Recognition } & \multirow[b]{2}{*}{$\begin{array}{l}\text { Political } \\
\text { Criticism }\end{array}$} & \multirow[b]{2}{*}{$\begin{array}{c}\text { Illegal } \\
\text { Relocation }\end{array}$} & \multicolumn{4}{|c|}{ Grounds for illegal relocation } & \multirow[b]{2}{*}{$\begin{array}{l}\text { Two } \\
\text { States }\end{array}$} & \multirow[b]{2}{*}{$\begin{array}{l}\text { East/West } \\
\text { Jerusalem }\end{array}$} & \multirow[b]{2}{*}{$\begin{array}{l}\text { Final } \\
\text { status }\end{array}$} & \multirow[b]{2}{*}{$\begin{array}{c}\text { Israel } \\
\text { withdrawal }\end{array}$} & \multirow[b]{2}{*}{$\begin{array}{l}1967 \\
\text { strict }\end{array}$} & \multirow[b]{2}{*}{$\begin{array}{r}1967 \\
\text { flex }\end{array}$} \\
\hline & & & & $\begin{array}{c}\text { UN } \\
\text { Resolutions }\end{array}$ & $\begin{array}{c}\text { International } \\
\text { Law }\end{array}$ & $\begin{array}{l}\text { IHL } \\
\text { HR }\end{array}$ & Consensus & & & & & & \\
\hline Indonesia & $\mathrm{x}$ & $\mathrm{x}$ & $\mathrm{x}$ & $\mathrm{x}$ & $x$ & $\mathrm{x}$ & $\mathrm{x}$ & $x$ & & $x$ & & & \\
\hline Iran & $x$ & $\mathrm{x}$ & $\mathrm{x}$ & $\mathrm{x}$ & $x$ & & & & & & & & \\
\hline Japan & & $x$ & & & & & $x^{\star *}$ & $x$ & & $x$ & $x$ & & \\
\hline Jordan & $x$ & $x$ & $x$ & $x$ & & & $x^{\star \star}$ & $x$ & $x$ & $x$ & $x$ & $x$ & $x$ \\
\hline Kazakhstan & & $x$ & & & & & & $x$ & $x$ & $x$ & $x$ & $x$ & \\
\hline Kuwait & & $x$ & $x$ & $x$ & $x$ & & & $x$ & $x$ & & $x$ & & $x$ \\
\hline Malaysia & $x$ & $x$ & $x$ & $x$ & $x$ & $x$ & $x$ & $x$ & $x$ & $x$ & $x$ & & $x$ \\
\hline Maldives & $x$ & & $x$ & $x$ & $x$ & & $x$ & $x$ & $x$ & $x$ & $x$ & & $x$ \\
\hline N. Korea & $x$ & $\mathrm{x}$ & $\mathrm{x}$ & & $\mathrm{x}$ & & $x$ & & $x$ & & & & \\
\hline Pakistan & $x$ & $x$ & $x$ & $x$ & $x$ & & & $x$ & $x$ & & & $x$ & \\
\hline Qatar & & & & & & & & $x$ & $x$ & & $x$ & $x$ & \\
\hline $\begin{array}{l}\text { Saudi } \\
\text { Arabia }\end{array}$ & & $x$ & $\mathrm{x}^{*}$ & $x$ & & & & $x$ & $x$ & $x$ & $x$ & $x$ & $x$ \\
\hline Syria & $x$ & $x$ & $x$ & $x$ & $x$ & & & & $x$ & & $x$ & & \\
\hline Thailand & & & & & & & & & & $x$ & & & \\
\hline Viet Nam & & & & & & & & $x$ & & & $x$ & & $\mathrm{x}$ \\
\hline Yemen & $x$ & $x$ & $x$ & $x$ & $x$ & & & $x$ & $x$ & & $x$ & $x$ & \\
\hline \multirow[t]{2}{*}{ STATES } & \multicolumn{7}{|c|}{ FIRST RESEARCH QUESTION } & \multicolumn{6}{|c|}{ SECOND RESEARCH QUESTION } \\
\hline & & & & & ounds for illegal & reloca & ation & & & & & & \\
\hline $\begin{array}{l}\text { LATIN } \\
\text { AMERICA }\end{array}$ & Recognition & $\begin{array}{l}\text { Political } \\
\text { Criticism }\end{array}$ & $\begin{array}{c}\text { Illegal } \\
\text { Relocation }\end{array}$ & $\begin{array}{c}\text { UN } \\
\text { Resolutions }\end{array}$ & $\begin{array}{c}\text { International } \\
\text { Law }\end{array}$ & $\begin{array}{l}\text { IHL } \\
\text { HR }\end{array}$ & Consensus & $\begin{array}{l}\text { Two } \\
\text { States }\end{array}$ & $\begin{array}{l}\text { East/West } \\
\text { Jerusalem }\end{array}$ & $\begin{array}{l}\text { Final } \\
\text { status }\end{array}$ & $\begin{array}{c}\text { Israel } \\
\text { withdrawal }\end{array}$ & $\begin{array}{l}1967 \\
\text { strict }\end{array}$ & $\begin{array}{l}1967 \\
\text { flex }\end{array}$ \\
\hline Argentina & & & & & & & & $\mathrm{x}$ & & $\mathrm{x}$ & $\mathrm{x}$ & & $x$ \\
\hline Brazil & & & & & & & & $\mathrm{x}$ & $x$ & $x$ & & & $x$ \\
\hline Bolivia & $x$ & $x$ & $x$ & $x$ & $x$ & $\mathrm{x}$ & $x^{\star \star}$ & $x$ & $x$ & & $x$ & $x$ & $x$ \\
\hline
\end{tabular}


Table 1. (Continued)

\begin{tabular}{|c|c|c|c|c|c|c|c|c|c|c|c|c|c|}
\hline \multirow{3}{*}{$\begin{array}{l}\text { STATES } \\
\text { LATIN } \\
\text { AMERICA }\end{array}$} & \multicolumn{7}{|c|}{ FIRST RESEARCH QUESTION } & \multicolumn{6}{|c|}{ SECOND RESEARCH QUESTION } \\
\hline & \multirow[b]{2}{*}{ Recognition } & \multirow[b]{2}{*}{$\begin{array}{l}\text { Political } \\
\text { Criticism }\end{array}$} & \multirow[b]{2}{*}{$\begin{array}{l}\text { Illegal } \\
\text { Relocation }\end{array}$} & \multicolumn{4}{|c|}{ Grounds for illegal relocation } & \multirow[b]{2}{*}{$\begin{array}{l}\text { Two } \\
\text { States }\end{array}$} & \multirow[b]{2}{*}{$\begin{array}{l}\text { East/West } \\
\text { Jerusalem }\end{array}$} & \multirow[b]{2}{*}{$\begin{array}{l}\text { Final } \\
\text { status }\end{array}$} & \multirow[b]{2}{*}{$\begin{array}{c}\text { Israel } \\
\text { withdrawal }\end{array}$} & \multirow[b]{2}{*}{$\begin{array}{l}1967 \\
\text { strict }\end{array}$} & \multirow[b]{2}{*}{$\begin{array}{l}196 \\
\text { flex }\end{array}$} \\
\hline & & & & $\begin{array}{c}\text { UN } \\
\text { Resolutions }\end{array}$ & $\begin{array}{l}\text { International } \\
\text { Law }\end{array}$ & $\begin{array}{l}\text { IHL } \\
\text { HR }\end{array}$ & Consensus & & & & & & \\
\hline Cuba & $x$ & $x$ & $x$ & $\mathrm{x}$ & $x$ & $\mathrm{x}$ & $\mathrm{x}$ & $x$ & $x$ & & $x$ & $\mathrm{x}$ & $\mathrm{x}$ \\
\hline Ecuador & & & & & & & & $x$ & $x$ & $x$ & & $x$ & \\
\hline El Salvador & & & $x^{*}$ & $x$ & & & & $x$ & & $x$ & & & \\
\hline Mexico & $x$ & $x$ & $x^{*}$ & $x$ & & & & $x$ & $x$ & $x$ & & & \\
\hline Nicaragua & & $x$ & $x$ & $x$ & & & & $\mathrm{x}$ & $x$ & & & $x$ & \\
\hline Paraguay & & & & & & & & $x$ & & $x$ & & & \\
\hline Perú & & $\mathrm{x}$ & & & & & & $x$ & & $x$ & & & \\
\hline Uruguay & & $\mathrm{x}$ & & & & & & $\mathrm{x}$ & & $x^{\star \star \star}$ & & & \\
\hline Venezuela & & $x$ & $x$ & $x$ & $x$ & $x$ & $x^{\star \star}$ & $x$ & $x$ & $x$ & $x$ & & $x$ \\
\hline \multirow[t]{2}{*}{ STATES } & \multicolumn{7}{|c|}{ FIRST RESEARCH QUESTION } & \multicolumn{6}{|c|}{ SECOND RESEARCH QUESTION } \\
\hline & & & & Grol & unds for illegal & reloca & ion & & & & & & \\
\hline $\begin{array}{l}\text { EUROPEAN } \\
\text { UNION }\end{array}$ & Recognition & $\begin{array}{l}\text { Political } \\
\text { Criticism }\end{array}$ & $\begin{array}{l}\text { Illegal } \\
\text { Relocation }\end{array}$ & $\begin{array}{c}\text { UN } \\
\text { Resolutions }\end{array}$ & $\begin{array}{c}\text { International } \\
\text { Law }\end{array}$ & $\begin{array}{l}\text { IHL } \\
\text { HR }\end{array}$ & Consensus & $\begin{array}{l}\text { Two } \\
\text { States }\end{array}$ & $\begin{array}{l}\text { East/West } \\
\text { Jerusalem }\end{array}$ & $\begin{array}{l}\text { Final } \\
\text { status }\end{array}$ & $\begin{array}{c}\text { Israel } \\
\text { withdrawal }\end{array}$ & $\begin{array}{l}1967 \\
\text { strict }\end{array}$ & $\begin{array}{l}1967 \\
\text { flex }\end{array}$ \\
\hline Belgium & $x$ & $x$ & $x^{*}$ & $x$ & & & $x$ & $x$ & & $x$ & & & $x$ \\
\hline Bulgaria & $x$ & $x$ & $x^{*}$ & $x$ & & & $\mathrm{x}$ & $x$ & & $x$ & & & \\
\hline Cyprus & & $x$ & $x^{*}$ & $x$ & & & $\mathrm{x}$ & $x$ & & $\mathrm{x}$ & & & \\
\hline Czech Rep. & & & & & & & & $x$ & $x$ & $x$ & & $x$ & \\
\hline Estonia & & & $x^{*}$ & $x$ & & & $\mathrm{x}$ & $x$ & & $x$ & & & \\
\hline France & $x$ & $x$ & $x$ & $x$ & $x$ & & $\mathrm{x}$ & $x$ & & $x$ & & & $x$ \\
\hline Germany & $x$ & $x$ & $x^{*}$ & $x$ & & & $x$ & $x$ & & $x$ & & & \\
\hline Greece & & $x$ & & & & & & $x$ & & $x$ & & & \\
\hline Hungary & $x$ & & & & & & & $x$ & & & & & \\
\hline
\end{tabular}


Table 1. (Continued)

\begin{tabular}{|c|c|c|c|c|c|c|c|c|c|c|c|c|c|}
\hline \multirow{3}{*}{$\begin{array}{l}\text { STATES } \\
\text { EUROPEAN } \\
\text { UNION }\end{array}$} & \multicolumn{7}{|c|}{ FIRST RESEARCH QUESTION } & \multicolumn{6}{|c|}{ SECOND RESEARCH QUESTION } \\
\hline & \multirow[b]{2}{*}{ Recognition } & \multirow[b]{2}{*}{$\begin{array}{l}\text { Political } \\
\text { Criticism }\end{array}$} & \multirow[b]{2}{*}{$\begin{array}{c}\text { Illegal } \\
\text { Relocation }\end{array}$} & \multicolumn{4}{|c|}{ Grounds for illegal relocation } & \multirow[b]{2}{*}{$\begin{array}{l}\text { Two } \\
\text { States }\end{array}$} & \multirow[b]{2}{*}{$\begin{array}{l}\text { East/West } \\
\text { Jerusalem }\end{array}$} & \multirow[b]{2}{*}{$\begin{array}{l}\text { Final } \\
\text { status }\end{array}$} & \multirow[b]{2}{*}{$\begin{array}{c}\text { Israel } \\
\text { withdrawal }\end{array}$} & \multirow[b]{2}{*}{$\begin{array}{l}1967 \\
\text { strict }\end{array}$} & \multirow[b]{2}{*}{$\begin{array}{l}1967 \\
\text { flex }\end{array}$} \\
\hline & & & & $\begin{array}{c}\text { UN } \\
\text { Resolutions } \\
\end{array}$ & $\begin{array}{c}\text { International } \\
\text { Law }\end{array}$ & $\begin{array}{l}\mathrm{IHL} \\
\mathrm{HR} \\
\end{array}$ & Consensus & & & & & & \\
\hline Ireland & & $x$ & $x^{*}$ & $\mathrm{x}$ & & & $\mathrm{x}$ & $x$ & & $\mathrm{x}$ & & & \\
\hline Italy & & $x$ & $x^{*}$ & $x$ & & & $x^{\star *}$ & $x$ & & $\mathrm{x}$ & & & \\
\hline Latvia & & & $x^{*}$ & $\mathrm{x}$ & & & & $x$ & & $\mathrm{x}$ & & & \\
\hline Lithuania & & & $x^{*}$ & $\mathrm{x}$ & & & $\mathrm{x}$ & $\mathrm{x}$ & & $\mathrm{x}$ & & & \\
\hline Luxembourg & $\mathrm{x}$ & $x$ & $\mathrm{x}$ & $x$ & & & $x / x^{\star \star}$ & $\mathrm{x}$ & & $x$ & & & $x$ \\
\hline Malta & & $x$ & $x^{*}$ & $x$ & & & $x / x^{\star *}$ & $x$ & & $x$ & & & \\
\hline Netherlands & & & $x$ & $x$ & $x$ & & $\mathrm{x}$ & $\mathrm{x}$ & & $\mathrm{x}$ & & $\mathrm{x}$ & \\
\hline Poland & $x$ & & $\mathrm{x}^{*}$ & $\mathrm{x}$ & & & $\mathrm{x}$ & $x$ & & $x$ & & & $\mathrm{x}$ \\
\hline Portugal & & $\mathrm{x}$ & $\mathrm{x}^{*}$ & $\mathrm{x}$ & & & $x$ & $x$ & & $x$ & & & \\
\hline Romania & & & $x$ & $\mathrm{x}$ & $x$ & & & $\mathrm{x}$ & & $\mathrm{x}$ & & & \\
\hline Slovakia & & $x$ & $x^{*}$ & $x$ & & & $x / x^{\star \star}$ & $x$ & & $\mathrm{x}$ & & & \\
\hline Slovenia & $x$ & $\mathrm{x}$ & $x$ & $x$ & $x$ & & $\mathrm{x}$ & $\mathrm{x}$ & & $\mathrm{x}$ & & & \\
\hline Spain & & & $x^{*}$ & $x$ & & & $\mathrm{x}$ & $\mathrm{x}$ & & $\mathrm{x}$ & & & \\
\hline Sweden & $x$ & $\mathrm{x}$ & $\mathrm{x}$ & $x$ & $x$ & & $\mathrm{x}$ & $x$ & & $\mathrm{x}$ & & & $x$ \\
\hline UK & $x$ & $x$ & $x^{*}$ & $x$ & & & $x$ & $x$ & $x$ & $x$ & & & $x$ \\
\hline STATES & \multicolumn{7}{|c|}{ FIRST RESEARCH QUESTION } & \multicolumn{6}{|c|}{ SECOND RESEARCH QUESTION } \\
\hline OTHER & \multicolumn{7}{|c|}{ Grounds for illegal relocation } & & & & & & \\
\hline $\begin{array}{l}\text { EUROPEAN } \\
\text { STATES }\end{array}$ & Recognition & $\begin{array}{l}\text { Political } \\
\text { Criticism }\end{array}$ & $\begin{array}{c}\text { Illegal } \\
\text { Relocation }\end{array}$ & $\begin{array}{c}\text { UN } \\
\text { Resolutions }\end{array}$ & $\begin{array}{l}\text { International } \\
\text { Law }\end{array}$ & $\begin{array}{l}\text { IHL } \\
\mathrm{HR}\end{array}$ & Consensus & $\begin{array}{l}\text { Two } \\
\text { States }\end{array}$ & $\begin{array}{l}\text { East/West } \\
\text { Jerusalem }\end{array}$ & $\begin{array}{l}\text { Final } \\
\text { status }\end{array}$ & $\begin{array}{c}\text { Israel } \\
\text { withdrawal }\end{array}$ & $\begin{array}{l}1967 \\
\text { strict }\end{array}$ & $\begin{array}{l}1967 \\
\text { flex }\end{array}$ \\
\hline Holy See & & & & & & & & & & $\mathrm{x}^{\star \star \star *}$ & & & \\
\hline Iceland & & & & & & & & $\mathrm{x}$ & & & & & \\
\hline Montenegro & & $x$ & & & & & & $x$ & & & & & \\
\hline $\begin{array}{l}\text { Russian } \\
\text { Feder. }\end{array}$ & $x$ & $x$ & & & & & $x$ & $x$ & $x$ & $x$ & $x$ & & \\
\hline
\end{tabular}


Table 1. (Continued)

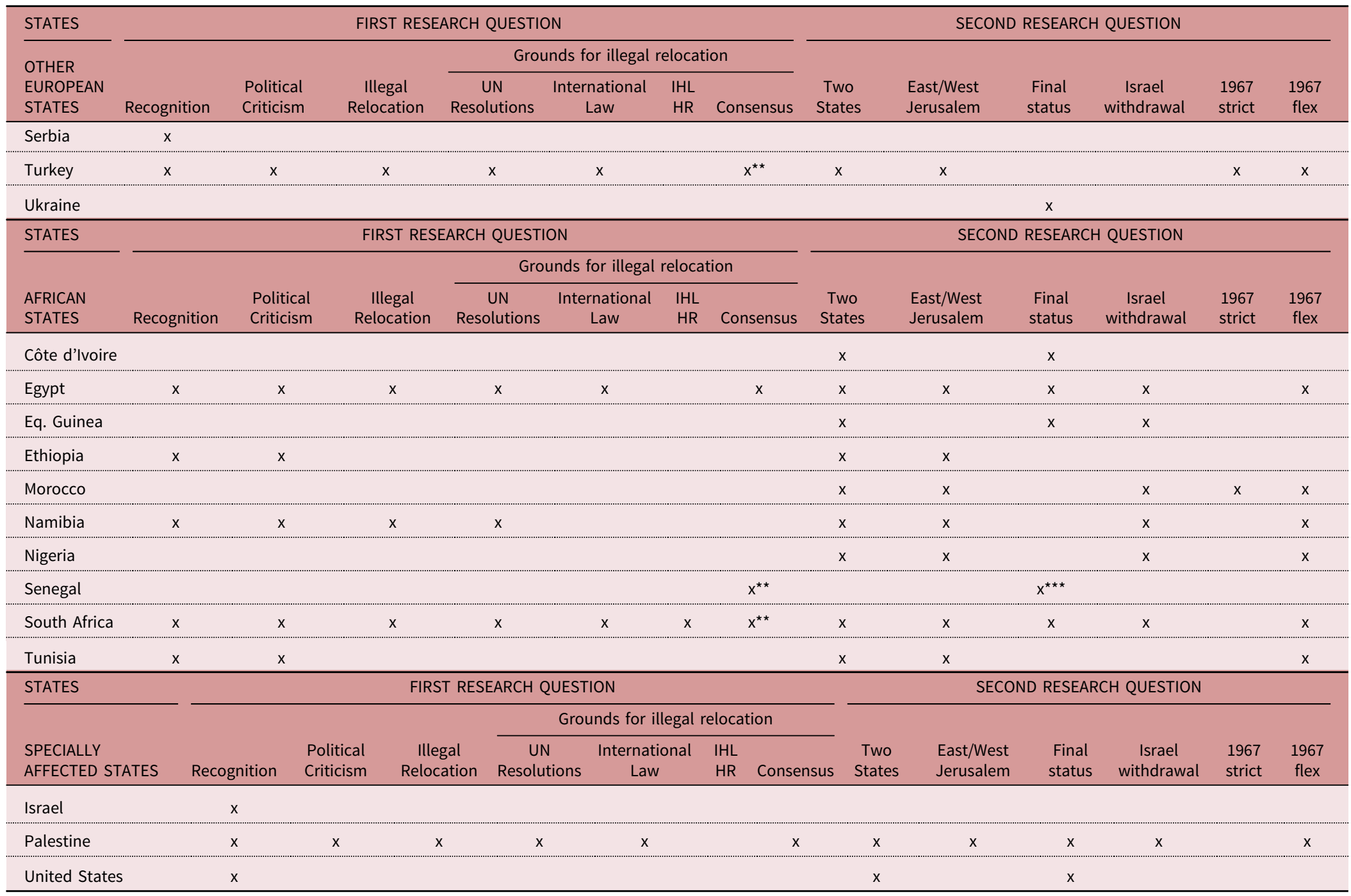

*Indirect recognition of illegality on the basis of UN SC Resolution 478 (1980).

** States refer to the "international consensus" in relation to the settlement of the Israeli-Palestinian issue and/or to the status of Jerusalem, not as the basis of the illegality of the US declaration.

$\star \star \star$ Jerusalem as corpus separatum subjected to a special international regime. 
With regard to our first research question, we identified four sub-questions stemming from the essential components of the rule on non-recognition. The first (logical) sub-question is expressed by column 1 of the table and concerns the nature of the US decision: does it amount to a form of recognition (or not) according to third states? It is clear, in our view, that the declaration of the American administration constitutes an act of recognition of Jerusalem as the capital of Israel. This is demonstrated by the language used, which openly speaks of recognition of a 'reality'. Nonetheless, some elements of ambiguity might derive from the wide caveat according to which the US is not taking position on '.. the specific boundaries of the Israeli sovereignty in Jerusalem'. It is therefore important to understand precisely to what extent third states have qualified the decision, directly or indirectly, as a form of recognition. We classified accordingly all the statements that used the words 'recognition' or 'recognize' with reference to the relocation of the US embassy. One should clarify also that even states that did not use such words in their statements but pointed out the need to respect Resolution 478 are, in our view, implicitly qualifying the decision of the US as a form of recognition. This stems from the content of this resolution, which, as has been pointed out in the second section, is centred on the obligation not to recognize the Basic Law declaring Jerusalem 'complete and united' as the 'capital of Israel'.

The second sub-question (columns 3 and 4) investigates whether states have qualified the US decision as a breach of international law (or not). The key question in this respect is quantitative: how many states did qualify the decision to relocate the US embassy as a violation of international law? How many states, conversely, decided to air their criticism in the form of a political statement? As we shall see, these two positions might be overlapping as political criticism (column 2 ), obviously, does not preclude a declaration of illegality (column 3 ).

The third sub-question (columns 4, 5, 6 and 7) tackles the legal basis invoked for the illegality. We thus analysed the relevant statements with a view to ascertaining the legal basis of each state's declaration of illegality. As the table shows, there are, in this respect, at least four different positions emerging from the practice. Some states argue that the illegality of the US decision is exclusively or mainly based on the relevant resolutions of the UNSC (column 4). Some states emphasize the importance of the violation of international law, at times by making a vague reference to 'international law' in general, at other times mentioning an applicable principle, such as the principle of self-determination or the principle according to which the acquisition of territory through the use of force is prohibited (column 5). As we shall see, in the latter case, some states refer the violation of the prohibition of forcible occupation to the US, although theoretically it should rather be considered as a violation made by Israel, in the first place, which entails a duty of non-recognition upon the US, as a consequence. A limited number of states also make specific reference to human rights and/or humanitarian law (column 6). Finally, a specific feature of the position of states with respect to the illegality of the relocation is that reference is often made to the existence of an 'international consensus' on Jerusalem and the wider Israeli-Palestinian issue (column 7). As will be seen in the ensuing section, the legal significance and the binding nature of this reference to a wide consensus remains to be explored.

With respect to the second research question, we highlighted the existence of some shared parameters for the settlement of the Israeli-Palestinian issue and the main elements of uncertainty in state practice. In particular, column 8 evidences that states almost unanimously agree on the principle 'two people, two states' but are divided on how to implement it. First, there is debate over the final status of Jerusalem and the borders of both Israel and the Palestinians' sovereignty over the city (and, more broadly, over the region of Palestine). Some states take the view that Jerusalem should be the capital of two states but put different emphasis either on the fact that East Jerusalem should be the capital of the Palestinian State or, conversely, on the fact that West Jerusalem is the capital of the Jewish State. We classified all of these statements under column 8 because, notwithstanding their being clearly different in terms of the political stance they express, from a legal point of view they both admit that the final status of Jerusalem revolves around the division of the city into two parts. 
To a different category (column 10) pertain those statements expressing the view that the final status of Jerusalem will have to be determined through negotiations. This position does not rule out the final division of the city into two parts - a view maintained by a significant number of the statements classified under this column - but is also compatible with different legal solutions such as the re-proposal of the corpus separatum theory, which is clearly reminiscent of the earlier UN resolutions, or with a comprehensive negotiation duly considering the problems of access to the Holy Sites located in the city. What really counts, however, in our opinion, is that the statements referring to Jerusalem as a final status issue express the view that the status of the city must not be determined de facto, but rather should be the outcome of a comprehensive negotiation. We then approached the wider problem of the final borders of the two states. In this respect, there is controversy on at least two key questions. Firstly, an issue under debate pertains to the procedure for the exercise of the Palestinian people's right to self-determination and most notably to Israeli withdrawal from the territories occupied in 1967 as a precondition for the initiation of meaningful negotiations on the final status of such territories. This question is of the utmost importance as presence on the ground necessarily impacts on the negotiation power of the parties. We therefore classified under column 11 all of the statements referring to the need for Israeli withdrawal from the territories occupied after June 1967, as a pillar for peace.

Finally (columns 12 and 13), we approached the crucial issue of the territorial unit on which the Palestinian State should be established. As highlighted in the review of the relevant UN resolutions (Section 2), there is wide consensus on the fact that the territorial basis of the state should be located on the territories occupied by Israel after 1967 (the West Bank and the Gaza Strip), which are invariably defined in the relevant UN resolutions as 'Palestinian' territories. In some of the states' declarations, however, the admissibility of territorial swaps comes to the surface leaving the precise determination of the territorial unit to the negotiations between the parties. From this perspective, the 1967 territories are the starting point of a negotiation that could bring about a different outcome. We therefore classified these statements as a form of flexible reference to the 1967 ceasefire lines: the legal parameter for the establishment of the final borders of the Palestinian State through negotiations (column 13). To the contrary, some states express the opinion that the territory of the Palestinian State coincides with the 1967 territorial unit and do not mention the possibility of altering such unit during the negotiation process. These statements are classified under column 12 .

\section{Analysis of the practice}

\subsection{The first research question: The anatomy of the duty of non-recognition}

While we are fully aware that the scholarly debate on the duty of non-recognition is wide and encompasses complex aspects ranging from the nature of the primary norm to be breached, the relevance of a centralized ascertainment of the breach, the consequences of the duty, and the prohibited conduct, ${ }^{61}$ it must be acknowledged that the practice of states detailed above is quite rudimentary when assessed in the light of the subtleties emerging from the literature. Statements do not describe explicitly the US decision to relocate its embassy as a violation of the duty of non-recognition, nor do they specify whether such a duty of non-recognition derives from a serious violation of a norm of peremptory nature by Israel or from relevant UNSC resolutions. Most of the time one is left with some indicia that would seem to confirm the validity

\footnotetext{
${ }^{61}$ See, among many, M. Dawidowicz, 'The Obligation of Non-Recognition of an Unlawful Situation', in J. Crawford, A. Pellet and S. Olleson (eds.), The Law of International Responsibility (2010), 677-86; S. Talmon, 'The Duty Not to "Recognize as Lawful" a Situation Created by Illegal Use of Force or Other Serious Breaches of a Ius Cogens Obligation: An Obligation without Real Substance?', in C. Tomuschat and M. Thouvenin (eds.), The Fundamental Rules of the International Legal Order. Jus Cogens and Obligations Erga Omnes (2006), 103-20; E. Milano, Unlawful Territorial Situations in International Law: Reconciling Effectiveness, Legality and Legitimacy (2006).
} 
of a given doctrinal construction but a significant effort of rationalization by the interpreter is needed. In the ensuing sub-sections, we will provide some tentative answers but a word of caution is necessary: the practice is far from being univocal in many respects.

On one single issue, however, we have certainty: a majority of states (164) condemn the relocation of the US embassy. The most prominent international organizations and groups, including the Organisation of Islamic Cooperation (OIC), the League of Arab States (LAS), the European Union (EU) as well as the Non-Aligned Movement (NAM), condemn the US move both from a political and a legal point of view. Political statements (163) range from qualifying the US move as a 'dangerous declaration' or as 'steps that might prejudice the historical, legal or religious status of the city of Al-Quds Ash-Sharif (OIC) to a 'decision, which will only increase tensions in the region' (AU) or as a decision having 'repercussions ... on the prospect of peace' (EU). Only a few states abstained from taking position, at least individually. ${ }^{62}$ Among these is Hungary that argued that there is no 'need to react to the US government's decision'. ${ }^{63}$ Israel, quite understandably, welcomed the decision as 'a milestone for Israel, for peace and for the world'. ${ }^{64}$ The position of the EU reveals the existence of different political attitudes among member states and the fracture within the bloc was confirmed by the decision of six European states to abstain when the UNGA adopted Resolution ES 10-19. A careful look at the EU member states' declarations, however, shows that the grounds put forward by the abstaining states correspond, to a large extent, to the legal basis invoked by the states that voted in favour of the resolution. The statement of Estonia, which spoke on behalf of 21 European states approving the resolution, is identical in its relevant passage to a statement released by Poland, which abstained ${ }^{65}$ In other words, EU states abstaining on the UNGA resolution acknowledge, directly or indirectly, the existence of a legal obligation not to locate diplomatic representations in Jerusalem ${ }^{66}$ with the consequence that the decision to abstain seems to have been determined by political convenience. ${ }^{67}$

Declarations of illegality were released by 155 states, either/both individually or/and within international organizations. The US decision to relocate its embassy is qualified as a form of 'recognition' of Jerusalem and condemned as unlawful under international law. In some cases, we inferred that a state considers the relocation as illegal because reference is made to UNSC Resolution 478 (1980), which qualifies Israeli measures seeking to alter the character and status of Jerusalem as null and void and calls upon member states to withdraw their diplomatic missions from 'the Holy City' ${ }^{68}$ Interestingly, in some declarations the decision of the US is not openly qualified as unlawful but the state nonetheless takes the view that adopting a similar course of action would be precluded by the applicable rules. These states, in essence, put forward an indirect

\footnotetext{
${ }^{62}$ Thailand, Viet Nam, Brazil, Paraguay, Argentina, Armenia, Georgia, Qatar, Hungary, Czech Republic, Iceland, the Holy See, Serbia, Ukraine, Morocco, Senegal, Cote d'Ivoire, Equatorial Guinea, Nigeria, and Canada.

${ }^{63} \mathrm{~V}$. Orbán, 'Hungary has successfully represented its position on the issue of Jerusalem', 15 December 2017, available at www.kormany.hu/en/the-prime-minister/news/hungary-has-successfully-represented-its-position-on-the-issue-of-jerusalem.

${ }^{64}$ UNSC, UN Doc. S/PV 8128 (2017).

${ }^{65}$ Poland, UNSC, The situation in the Middle East, including the Palestinian question, UN Doc. S/PV 8256 (2018); Estonia, UNGA, UN Doc. A/ES-10/PV.37 (2017).

${ }^{66}$ Romania, UNGA, UN Doc. A/ES-10/PV.37 (2017); Poland, UNSC, The situation in the Middle East, including the Palestinian question, UN Doc. S/PV 8256 (2018); Foreign Minister Rinkēvičs, 'Only by observing the interests of both parties, a two-state solution that involves Israel and Palestine can be achieved', 7 June 2018, available at www.mfa.gov.lv/en/ news/latest-news/60353-foreign-minister-rinkevics-only-by-observing-the-interests-of-both-parties-a-two-state-solution-thatinvolves-israel-and-palestine-can-be-achieved.

${ }^{67}$ Press release on the draft resolution on the status of Jerusalem, 21 December 2017, available at www.mae.ro/en/node/ 44555; Latvia, UNGA, UN Doc. A/ES-10/PV.37 (2017); 'The Government is not adapting its foreign policy to third parties', 13 December 2017, available at www.kormany.hu/en/ministry-of-foreign-affairs-and-trade/news/the-government-is-notadapting-its-foreign-policy-to-third-parties.

${ }^{68}$ These states are indicated in the table with an asterisk $\left(^{*}\right)$.
} 
declaration of illegality by stating that, complying with international law or the applicable UN resolutions, they shall not adopt the same decision as the US. ${ }^{69}$

\subsubsection{The legal bases of the alleged illegality}

As is well known, the question as to the nature of the primary norm whose breach would bring about a duty of non-recognition is answered by Article 41(2) of the ILC Articles on State Responsibility by referring to a 'serious breach' of a 'peremptory norm'. The duty of nonrecognition is therefore conceptualized by the ILC, together with the duty not to render aid or assistance, as a peculiar consequence of a form of aggravated responsibility. It is no wonder that this degree of theoretical sophistication is extraneous to state practice and that none of the declarations make explicit reference to the concept of peremptory norm. The fact remains, however, that a substantive number of statements utilize a norm that is undoubtedly peremptory as one of the main legal bases of their claim of illegality of the US embassy relocation.

States recall peremptory norms of international law such as the 'prohibition of acquisition of territory by force' (NAM, Yemen, Bolivia, Venezuela, and Palestine) and the right of selfdetermination of people (Malaysia and Iran). Reference to peremptory norms is made, sometimes directly and at other times indirectly, by recalling relevant UNSC resolutions. A case of direct reference is Yemen, which argues that:

[ $\mathrm{t}$ ]he decision taken by the United States Administration on 6 December 2017 on the status of Jerusalem .... is a dangerous violation and breach of international law and the Charter of the United Nations, which provides for the inadmissibility of the acquisition of land by force. ${ }^{70}$

Similarly, according to Iran,

$[t$ ]he recent illegal decision by the United States Administration to recognize Al-Quds as the capital of the Israeli regime and to move its embassy to this holy city has made it crystal clear that the United States ... harbours no respect for the legitimate rights of the Palestinian people, including their right to self-determination. ${ }^{71}$

Along the same lines, Malaysia argues that the US decision is also an infringement of the Palestinian people's rights and their right to self-determination'. ${ }^{72}$ What is worth noting is that these statements seem to depart from the ILC conceptualization and attribute the violation of the peremptory norm directly to the US, rather than Israel. It is thus unclear whether, in the views of those states, the illegality of the US embassy relocation derives from a direct violation of peremptory norms by the US itself, or whether their reasoning includes logical leaps with the consequence that the violation of the peremptory norm (i.e., inadmissibility of the acquisition of land by force or breach of self-determination) shall be attributable to Israel and the illegality of the US decision shall be derived from the violation of the secondary norm on non-recognition. On the contrary, a two-step approach from the primary norm to the secondary one, in line with the logic of the ILC

\footnotetext{
${ }^{69}$ See, for instance, Italy, Statement by Minister Alfano on Jerusalem, 7 December 2017, available at www.esteri.it/mae/en/ sala_stampa/archivionotizie/comunicati/dichiarazione-del-ministro-alfano_0.html; UN Doc. S/PV.8128 (2017); El Salvador expresa su preocupación por la situación en Gaza, 15 May 2018, on file with the authors, reproduced in the Annex; Poland, 'EU foreign ministers meet on Monday to discuss the situation in the Middle East and other issues', 11 December 2017, available at msz.gov.pl/en/news/eu_foreign_ministers_meet_on_monday_to_discuss_the_situation_ in_the_middle_east_and_other_issues.

${ }^{70}$ UNGA, UN Doc. A/ES-10/PV.37 (2017).

${ }^{71}$ Ibid.

${ }^{72}$ Ibid. See also, 'Bahrain affirms that the US administration's decision to recognize Jerusalem as the capital of Israel threatens the peace process in the Middle East', 7 December 2017, available at www.mofa.gov.bh/Default.aspx?tabid= 7824\&language $=$ en-US\&ItemId $=8244$.
} 
Articles, emerges from the OIC's statement which 'calls for not tolerating any state that accepts the Israeli claims about the occupied city of Al-Quds, or takes measures that consecrate Israel's occupation of the holy city'. ${ }^{73}$

Generally, NAM countries adopt a sort of holistic approach, invoking a panoply of legal bases, including inter alia the Fourth Geneva Convention. ${ }^{74}$ A specificity of the 120 NAM states, both within the movement and individually, is that they refer to norms of International Humanitarian Law whose jus cogens nature is still disputed in the scholarly debate. ${ }^{75}$ Reference to international humanitarian law and to the Fourth Geneva Convention can also be drawn indirectly from UNSC Resolution 2334. As has been seen in Section 2, Resolution 2334 affirms that the establishment by Israel of settlements 'flagrantly' violates the Fourth Geneva Convention and calls upon states to distinguish in their dealings between the territory of the State of Israel and the territories occupied since 1967. Therefore, the US move of its embassy to Jerusalem - a territory occupied by Israel since 1948 (West) and 1967 (East), and where the policy of settlement is currently implemented would entail a form of recognition incompatible with international law. States that indirectly endorse this view are Kuwait ${ }^{76}$, Nicaragua, ${ }^{77}$ and the 57 states of the OIC. ${ }^{78}$

Other norms invoked as grounds for illegality range from the UNSC resolutions and (vaguely) international law to the reference to the existence of a (legal) consensus, often enshrined in the UNSC resolutions themselves. UNSC resolutions are often enumerated precisely and most frequently include: UNSC Resolution 242 (1967), Resolution 338 (1973), Resolutions 476 and 478 (1980), and Resolution 2334 (2016). In some cases, the UN Charter is expressly recalled as the basis of the illegality of the US decision. ${ }^{79}$

\footnotetext{
${ }^{73} \mathrm{Al}$-Othaimeen: We hope that the Islamic Summit will reach effective measures on what is happening in Palestine, 18 May 2018, available at www.un.org/unispal/document/oic-secretary-general-al-othaimeen-we-hope-that-the-oic-islamic-summitwill-reach-effective-measures-on-what-is-happening-in-palestine/ (emphasis added). See also, Maldives, UNGA, Meeting Records, UN Doc. A/ES-10/PV.37 (2017).

${ }^{74}$ Venezuela on behalf of NAM, UNGA, Meeting Records, UN Doc. A/ES-10/PV.37 (2017); Cuba, UNGA, Meeting Records, UN Doc A/ES-10/PV.37 (2017).

${ }^{75}$ NAM, Yemen, Bolivia, and Venezuela, UNGA, Meeting Records, UN Doc. A/ES-10/PV.37 (2017); Palestine, UN Doc. S/ PV.8128 (2017). Column 6 of the table only collects statements that made direct reference to the Fourth Geneva Convention or to International Humanitarian Law more broadly. Indirect references through UNSC Resolution 2234 are not considered. See R. N. Navia, 'International Peremptory Norms (Jus Cogens) and International Humanitarian Law', in Man's Inhumanity to Man: Essays on International Law in Honour of Antonio Cassese (2003), 595; T. Meron, 'The West Bank and International Humanitarian Law on the Eve of the Fiftieth Anniversary of the Six-Day War', (2017) 111 American Journal of International Law 357.

${ }^{76}$ Kuwait, UNSC, Meeting Records, UN Doc. S/PV. 8214 (2018), '[the decision to transfer the United States embassy] is null and void since it is in explicit contravention of resolutions ... In violating Security Council resolutions, particularly 2334 (2016), Israel, the occupying Power, is maintaining its expansionist, illegal and illegitimate activities'.

${ }^{77}$ Nicaragua, UNGA, Meeting Records, UN Doc. A/ES-10/PV.37 (2017), 'Nicaragua expresses its deep concern about and rejection of recent unilateral actions aimed at modifying the character, status and demographic composition of Jerusalem, in flagrant violation of the relevant General Assembly and Security Council resolutions, including resolution 2334 (2016), which clearly states that no changes to the 4 June 1967 lines will be legally recognized, including with regard to East Jerusalem, other than those agreed by the parties.'

${ }^{78}$ OIC, Resolution Submitted to the Extraordinary Meeting of the Council of Foreign Ministers to Review the Situation Following the US Administration's Recognition of the City of Al-Quds Ash-Sharif as the Alleged Capital of Israel, the Occupying Power, and its Decision to Move the US Embassy to Al-Quds, OIC/EX-CFM/2017/PAL/RES, 13 December 2017, 'this dangerous declaration, which aims to change the legal status of the City of Al-Quds Ash-Sharif, is null and void, has no legal value and lacks any legitimacy, as being a serious violation of the international law, the signed agreements and the relevant resolutions of international legitimacy and the United Nations, particularly the UN Security Council resolutions .... calls upon them [states] to distinguish, in their dealings, between Israel and the Palestinian territory occupied since 1967'.

${ }^{79}$ See Yemen, UNGA, Meeting Records, UN Doc. A/ES-10/PV.37 (2017).
} 


\subsubsection{The UN resolutions as binding documents}

The circumstance that many states ground the illegality of the US decision on the applicable UN resolutions brings to the surface the scholarly debates as to what type of acts of the UNSC are binding in general ${ }^{80}$ and which ones, among the many adopted on the Middle East, have binding nature specifically. ${ }^{81}$ In light of the practice on the US embassy relocation, some authors have already argued that the UN resolutions 'may simply have operated as a mere restatement' of a duty of non-recognition 'already imposed under general international law' ${ }^{82}$ While this approach undoubtedly captures some of the positions adopted by third states, in our view the practice seems to offer a more coloured picture. The language used by the declarations allows us to infer that some states consider the UN resolutions as binding per se; while other states treat the resolutions as binding because they mirror international law. Egypt, for instance, argued that '... it might be appropriate to recall the most important binding Council resolutions on Jerusalem, longstanding and more contemporary ones alike'. Mentioning explicitly Resolutions 242 (1967), 478 (1982), and 2334 (2016), the Egyptian representative affirmed that ' $\mathrm{t}]$ hey are the binding Security Council resolutions that all countries have pledged, pursuant to the Charter of the United Nations, to implement and abide by.$^{83}$ Similar statements were released by Venezuela, Bolivia, and Saudi Arabia. France also observed that UNSC Resolutions 476 (1980) and 478 (1980) include two principles:

[f]irst, any measure aimed at altering the status of Jerusalem, as well as the geographical, demographic and historical characteristics of the city, is considered null and void and must be abandoned. Secondly, all United Nations Member States that have established diplomatic missions in Jerusalem must remove them from the city. ${ }^{84}$

The use of the word 'must', seems to imply that France considers the prescription of those resolutions as mandatory. Jordan, by contrast, argues that any measures aiming to alter the legal nature and status of Jerusalem 'are null and void as confirmed by various relevant Security

\footnotetext{
${ }^{80} \mathrm{H}$. Kelsen, The Law of the United Nations (1951), at 293; B. Simma et al. (eds.), The Charter of the United Nations. A Commentary, vol. I (2012), at 792; J. P. Cot, A. Pellet and M. Forteau, La Charte des Nations Unies. Commentaire article par article, vol. I (2005), at 912; D. H. Joyner, 'Legal Bindingness of Security Council Resolutions Generally, and Resolution 2334 on the Israeli Settlements in Particular', EJIL:Talk!, 9 January 2017, available at www.ejiltalk.org/legal-bindingness-of-securitycouncil-resolutions-generally-and-resolution-2334-on-the-israeli-settlements-in-particular; A. Tzanakopoulos, Disobeying the Security Council: Countermeasures against Wrongful Sanctions (2011), at 57-9; Legal Consequences for States of the Continued Presence of South Africa in Namibia (South West Africa) notwithstanding Security Council Resolution 276 (1970), Advisory Opinion of 21 June 1971, [1971] ICJ Rep. 11, at 114.

${ }^{81}$ Concerning the binding nature of UNSC Res. 242 (1967): Soviet Union, UNSC, The situation in the Middle East, UN Doc. S/8495 (1968), at 4; Nigeria, UN Doc. S/PV.1718 (1973), para. 57; India, UN Doc. S/PV.1735 (1973), para. 81 and Pakistan, UN Doc. S/PV.1894 (1976), para. 147; Kuwait, UN Doc. S/PV.2157 (1979), para. 7; Tunisia, UN Doc. S/PV.2200 (1980), para. 66; China, UN Doc. S/PV.2965 (1990), at 10; Canada, UN Doc. S/PV.4525 (2002), at 13; Singapore and Mexico, UN Doc. S/PV.4506 (2002), at 30, 37. Against the binding nature of UNSC Res. 242 (1967): Brazil, UN Doc. S/OV.1382 (1967), para. 124. Concerning UNSC Res. 338 (1973), the UNSC itself has repeatedly stated its implementation is mandatory for member states: UNSC, Res. 338, UN Doc. S/RES/338 (1973); UN Doc. S/RES/369 (1975); UN Doc. S/RES/420 (1977); UN Doc. S/RES/ 429 (1978); UN Doc. S/RES/470 (1980); UN Doc. S/RES/506 (1982); UN Doc. S/RES/557 (1984). As to UNSC Res. 478 (1980), the US has argued that it is not binding: US, UN Doc. S/PV.8139 (2017), at 4; while Egypt has maintained that this is a binding Security Council resolution': Egypt, UN Doc. S/PV.8128 (2017). Concerning UNSC Res. 2234 (2016), see D. H. Joyner, supra note 80.

${ }^{82} \mathrm{M}$. Arcari, 'The Relocation of the US Embassy to Jerusalem and the Obligation of Non-Recognition in International Law', (2018) 50 QIL 1, at 6.

${ }^{83}$ UN Doc. S/PV 8128 (2017) (emphasis added). See also Venezuela and Bolivia, UN Doc. A/ES-10/PV.37 (2017); Saudi Arabia, UN Doc. S/PV. 8167 (2018).

${ }^{84}$ France, UN Doc. S/PV.8128 (2017) (emphasis added).
} 
Council Resolutions' ${ }^{85}$ Similar statements were released by Bahrain and Syria. On the same path, South Africa recalls:

.. all United Nations resolutions, including Security Council resolutions 476 (1980) and 478 (1980), by which the Council, inter alia, reconfirmed that all legislative and administrative measures and actions taken by Israel, the Occupying Power, that purported to alter the character and status of the Holy City of Jerusalem had no legal validity and must be rescinded forthwith. ${ }^{86}$

In our view, the use of the verb 'confirm' in these cases points out that the resolutions are treated as texts mirroring some pre-existing international law obligations.

Finally, it is of note that a number of states (87) refer, directly or implicitly, to the existence of an 'international consensus' which would have been breached by the decision to relocate the embassy. Among these are the EU and its member states that 'will continue to respect the international consensus on Jerusalem embodied in, inter alia, UNSCR 478, including on the location of their diplomatic representations until the final status of Jerusalem is resolved'. ${ }^{87}$ Some states even speak of 'internationally agreed parameters' recalling the idea that a sort of (express or tacit) worldwide agreement exists on the issue of Jerusalem and Palestine, more broadly. ${ }^{88}$ Reference to a consensual element, however, is never presented as the only legal argument to qualify the behaviour of the US.

As will be discussed further, below, in our treatment of the second research question, reference to this stratification of international peace plans and initiatives is also made to substantiate the existence of some agreed parameters for the solution of the crisis. ${ }^{89}$

\subsubsection{The relocation as an unlawful form of aid or assistance}

Some states qualify the behaviour of the US as an unjustified form of endorsement or complicity with the violations attributable to Israel. Malaysia, for instance, states that the US decision:

... not only contravenes and undermines the relevant Security Council Resolutions but it would also embolden Israel, the Occupying Power to continue to execute its brutal occupation and repressive policies in the Occupied Palestinian Territory - a clear violation of international law, including humanitarian law. ${ }^{90}$

Along the same lines, Indonesia argues that the US decision 'supports illegal acts committed by Israel in violation of international humanitarian and international human rights law'. ${ }^{91}$ Similarly, the OIC maintains that the inauguration of the US embassy in Al Quds 'further emboldens Israel, the occupying power to set up its illegal and criminal actions against the Palestinian people'. ${ }^{92}$

\footnotetext{
${ }^{85}$ Jordan, UN Doc. S/PV 8128 (2017); Bahrain's Statement, supra note 72; Syria, UN Doc. A/ES-10/PV.37 (2017) (emphasis added).

${ }^{86}$ UN Doc. A/ES-10/PV.37 (2017) (emphasis added).

${ }^{87}$ Statement by HR/VP Federica Mogherini on the announcement by US President Trump on Jerusalem, 6 December 2017, available at eeas.europa.eu/headquarters/headquarters-homepage/36910/statement-hrvp-federica-mogherini-announcementus-president-trump-jerusalem_en (emphasis added). See also, among others, France, UN Doc. S/PV 8256 (2018); Indonesia, UN Doc. A/ES-10/PV.37 (2017).

${ }^{88}$ France, UN Doc. S/PV 8244 (2018).

${ }^{89}$ States that refer to the international consensus in relation to the settlement of the Israeli-Palestinian issue and/or the status of Jerusalem are identified with double asterisk $\left.{ }^{* *}\right)$ in the table.

${ }^{90}$ Malaysia, UN Doc. S/PV 8244 (2018). See also, Turkey, UN Doc. S/PV 8244 (2018), 'Inaction in the face of persistent noncompliance with international law and Security Council resolutions, including resolution 2334 (2016), further emboldens Israel's recklessness'; Palestine, UN Doc. S/PV 8244 (2018) '[i]t is therefore extremely regrettable that, instead of rejecting Israel's illegal actions, a few States are emboldening its impunity'.

${ }^{91}$ Indonesia, UN Doc. A/ES-10/PV.37 (2017).

${ }^{92}$ OIC, OIC Final communiqué, 18 May 2018, available at oic-oci.org/docdown/?docID=1865\&refID=1079.
} 
These positions mirror the conceptualization of the consequences of serious violations of peremptory norms put forward by Article 41(2) of the ILC Articles, which imposes upon states not only a duty not to recognize as lawful a situation created by a serious breach of a peremptory norm, but also the obligation not to render aid or assistance in maintaining such a situation. Theoretically, the ILC construed the prohibition contained in paragraph 2 as an autonomous obligation insofar as the actions concerned do 'not necessarily imply recognition of the situation created by serious breaches in the sense of article 40'. However, the above-mentioned states consider the relocation of the embassy as both a violation of the duty of non-recognition and the duty not to render aid or assistance.

\subsubsection{The consequences of the unlawfulness: The relocation as an act affected by nullity}

Several states (127) consider the US decision as 'null and void'. Turkey, for instance, underlines that ' $\mathrm{t}$ ] he OIC unanimously rejected the decision as null and void in accordance with Security Council Resolution 476/1980, which censored, in the strongest terms, a similar decision taken by the Israeli parliament in 1980'. ${ }^{93}$ Along similar lines, the Maldives state:

[t]he Security Council has declared ... that Israel's occupation of the State of Palestine is illegal, its annexation of East Jerusalem is illegal, and the decision by any country to recognize Jerusalem as Israel's so-called capital and the relocation of diplomatic missions to Jerusalem, are also illegal and should be construed by the international community as null and void. ${ }^{94}$

One might therefore wonder what the meaning of nullity is and what the obligations arising from this double nullity - both of the annexation of Jerusalem and of its recognition - are. The statements, however, do not clarify which prohibitions ensue from the qualification as nullity of the relocation of the embassy. One might take the view that the obligation of third parties not to enter into any diplomatic relations with the US embassy in Jerusalem would be a logical corollary of the nullity of the relocation. The practice, however, does not shed light on this aspect.

With respect to the theoretical basis of nullity, it has been rightly observed that in the international legal system, nullity does not follow the decision of a Court depriving the act of any legal effect but the assessment made by each 'interested participant', either individually or collectively, within international organizations. ${ }^{95}$ With the consequence that acts are 'voidable' in the sense that they are 'provisionally or at least potentially, valid acts that can be voided by an appropriate extra-judicial declaration'. ${ }^{96}$ Therefore, as Reisman and Pulkowski observed, '[a]n act may be treated as valid by the international community until interested participants promote a policy of its non-recognition'. ${ }^{97}$ An assessment made by a 'third' multilateral organization, such as the

\footnotetext{
${ }^{93}$ Turkey, UN Doc. A/ES-10/PV.37 (2017); Kuwait, UN Doc. S/PV. 8214 (2018), ‘ . . We remind the Council of the serious potential consequences of the decision to transfer of the United States embassy to Jerusalem ... That decision is null and void since it is in explicit contravention of resolutions 242 (1967), 338 (1973), 476 (1980), 478 (1980) and 2334 (2016)'; Yemen, UN Doc. A/ES-10/PV.37 (2017) ' ... The decision taken by the United States . . . is considered to be null and void and provides no legal basis for changing the status of occupied Jerusalem'; NAM, UN Doc. S/PV.8167 (2018) ' ... any attempts to alter the character, status or demographic composition of the city of Jerusalem, as set out in the relevant Security Council and General Assembly resolutions, have no legal effect and are null and void, and we also stress that Jerusalem is a final-status issue to be resolved through negotiations'; France, UN Doc. S/PV.8128 (2017) ' . . any measure aimed at altering the status of Jerusalem, as well as the geographical, demographic and historical characteristics of the city, is considered null and void and must be abandoned'.

${ }^{94}$ Maldives, UN Doc. A/ES-10/PV.37 (2017).

${ }^{95} \mathrm{H}$. W. Baade, 'Nullity and Avoidance in Public International Law: A Preliminary Survey and A Theoretical Orientation', (1969) 39(3) Indiana Law Journal 497, at 553. See also Legal Status of Eastern Greenland (Denmark v. Norway), PCIJ Rep. Series A/B No. 53, Dissenting Opinion [Judge Anzilotti], para. 306.

${ }^{96}$ Baade, ibid., at 553.

${ }^{97}$ W. M. Reisman and D. Pulkowski, 'Nullity in International Law', (2006) Max Planck Encyclopaedia of Public International Law (on-line ed.), para. 3.
} 
UNSC, that an act is null and void, may contribute to confirm, in the eyes of the international community, the fact that the act shall be deprived of any effect whatsoever. ${ }^{98}$

In this respect, some of the statements confirm that states consider the relocation as illegal and thus 'voidable' by the international community through non-recognition: for instance, according to the above-mentioned statement by the Maldives 'the relocation of diplomatic missions to Jerusalem ... should be construed by the international community as null and void'. Pakistan, conversely, argues that nullity is an intrinsic quality of the relocation (' $[\mathrm{m}] \mathrm{y}$ delegation believes that the United States veto earlier this week in the Security Council ... attempted to legitimize a declaration that is already null and void and lacks any legality'), but at the same time admits that " $\mathrm{t}]$ hrough draft resolution ... the rest of the world will say ... that it cannot and will not be complicit in any act of illegality'. ${ }^{99}$ Saudi Arabia, finally, observes ' . . that any measure taken by the occupying Power on Jerusalem is null and void. Any recognition of Jerusalem as the capital and any relocation of the embassy of any country to Jerusalem are null and void'. ${ }^{00}$

For a majority of states an ascertainment by UN organs remains, in any case, a pivotal element for the nullity of the relocation, ${ }^{101}$ confirming that the UN still represents the main forum where the assessment of the practice on non-recognition takes place.

\subsection{The second research question: The prospects for peace}

\subsubsection{The status of Jerusalem}

The final settlement of the Israeli-Palestinian question cannot avoid the quest for a solution to the status of Jerusalem. As recognized by the representative of France within the Security Council, 'there will be no two-states solution without agreement between the parties on Jerusalem'. ${ }^{102}$ In this respect, it should be noted that 164 states take a position which is reminiscent of the approach of the Oslo accords, when Jerusalem was qualified as an autonomous 'final status issue' to be decided by relevant parties through negotiation. Among European states, in particular, there is wide agreement on the fact that the status of Jerusalem shall be determined during final status negotiations and on the circumstance that the city shall be the capital of both states. ${ }^{103}$

\footnotetext{
${ }^{98}$ Ibid. The Authors made clear that '[e]ven when a claim to nullify a prior decision or at succeds, legal consequences may still flow from the annulled conduct or act ..., such as the obligations concerning occupation bellica, attach irrespective of the legal validity of the territorial acquisition'. See also A. Tancredi, 'Lo Stato nel diritto internazionale tra effettività e legalità/ legittimità', (2011) XVI Ars Intepretandi - Annuario di ermeneutica giuridica 150.

${ }^{99}$ Pakistan, UN Doc. A/ES-10/PV.37 (2017); Jordan, UN Doc. S/PV.8128 (2017), ' $t$ the Hashemite Kingdom believes that any unilateral measure aiming to impose a new situation on the ground is null and void. That is why Jordan rejects this decision ...'.

${ }^{100}$ Saudi Arabia, UN Doc. S/PV. 8167 (2018) (emphasis added).

${ }^{101}$ Kuwait, UN Doc. S/PV 8256 (2018), ‘ . . . a blatant violation of the relevant Council resolutions, particularly resolutions 476 (1980) and 478 (1980), which considered such unilateral actions null and void, with no legal effect'; Turkey, UN Doc. A/ ES-10/PV.37 (2017) ' . . null and void, in accordance with Security Council resolution 476 (1980), which censored, in the strongest terms, a similar decision taken by the Israeli parliament in 1980'; Saudi Arabia, UN Doc. S/PV. 8167 (2018), '[t]he Council has adopted a number of resolutions, including, for example, resolutions 465 (1980), 476 (1980), 478 (1980) and 2334 (2016). All of those resolutions stress that all unilateral decisions that aim to change the historical and legal status of Jerusalem and to impose a fait accompli are null and void'; OIC, supra note 92, '... null and void, has no legal value and lacks any legitimacy, as being a serious violation of the international law, the signed agreements and the relevant resolutions of international legitimacy and the United Nations, particularly the UN Security Council resolutions No. 252 (1968); 267 (1969); 465, 476, and 478 (1980); and 2334 (2016), and defiance of the international will and unanimity'.

${ }^{102}$ France, UN Doc. S/PV 8256 (2018); Palestine, UN Doc. S/PV.8128 (2017).

${ }^{103}$ Estonia's speech on behalf of the EU, Austria, Belgium, Bulgaria, Cyprus, Denmark, Estonia, Finland, France, Germany, Ireland, Italy, Lithuania, Luxembourg, Malta, the Netherlands, Portugal, Slovakia, Slovenia, Spain, Sweden, and the United Kingdom: UN Res. A/ES-10/PV.37 (2017) and Poland, UN Doc. S/PV 8256 (2018); Foreign Minister Rinkēvičs, supra note 66. Only the UK expressly states that it 'regard[s] East Jerusalem as part of the occupied Palestinian territories', thus admitting that West Jerusalem is not; see United Kingdom, UN Doc. S/PV.8128 (2017). The Czech Republic de facto considers West Jerusalem as the capital of Israel, having opened both an honorary consulate to Israel and a Czech Centre there; see Statement of the MFA of the Czech Republic, 26 April 2018, available at www.mzv.cz/ramallah/en/news/statement_of_the mfa_of_the_czech.html.
} 
A wide majority of states (133) regard East Jerusalem as belonging to the Palestinian State, even though they invariably admit that Jerusalem represents a final status issue to be decided during the peace process. The Russian Federation, for example, believes 'that a fair and lasting solution to the protracted Palestinian-Israeli conflict should be based on international law, including UN Security Council and General Assembly resolutions that provide for settling all aspects of the final status of the Palestinian territories, including the highly delicate issue of Jerusalem, through direct Palestinian-Israeli talks', on the one hand, and 'sees East Jerusalem as the capital of the future Palestinian State and West Jerusalem as the capital of the State of Israel', on the other. ${ }^{104}$ These statements affirm that Jerusalem should be the capital of both states but at the same time highlight that its final status cannot be resolved by merely dividing the city into two parts. Presumably, they acknowledge that, in the case of the Holy City, there are more complex issues to be addressed, such as the problems related to access to the Holy Places.

Overall, there is wide consensus on the fact that the outcome of the final status negotiations shall not depart from Jerusalem as the capital of both states. ${ }^{105}$ Only two states, Uruguay and the Holy See, took the view that the final status of Jerusalem would have to be 'a corpus separatum subjected to a special international regime', ${ }^{106}$ recalling the original plan promoted by the UN in 1947. The precise administrative status of Jerusalem, however, is left unprejudiced, as it will be decided upon during the negotiations: a divided city or a shared capital? With what arrangements to ensure access to the Holy Places? These are the questions to be addressed during the negotiations.

\subsubsection{The borders of the two states}

In many respects, the Israeli-Palestinian question appears as an intractable problem. On one single issue, however, we have certainty. There is a virtually unanimous consensus (166) on the need for two states living in peace and security in the region. This is clearly visible in the statements that we collected. Only Pakistan mentioned the one-state solution with the aim of discharging it swiftly. ${ }^{107}$ This shows that the re-emerging cultural debate on the one-state solution has not contaminated state practice yet. ${ }^{108}$ A number of states (127) refer expressly to the existence of some agreed parameters concerning the settlement of the Israeli-Palestinian issue. ${ }^{109}$ China, for instance, mentions the 'long-standing foundation for the settlement of the question of Palestine, ${ }^{110}$ Malta, the existence of an 'international consensus on the issue', 111 Japan, Luxembourg and many other EU states refer to '[well-]known parameters' for the final status of Jerusalem and/or the solution of the

\footnotetext{
${ }^{104}$ Russian Federation, Comment by the Information and Press Department on US recognition of Jerusalem as the capital of Israel, 7 December 2017, available at www.mid.ru/en/web/guest/maps/us/-/asset_publisher/unVXBbj4Z6e8/content/id/ 2980367. See also, Kazakhstan, UN Doc. S/PV.8128 (2017) and UN Doc. S/PV 8265 (2018); Bahrain, UN doc. S/PV 8244 (2018).

${ }^{105}$ Iran seems to envisage Jerusalem as the sole capital of Palestine. See Islamic Republic of Iran Newsletter, 6 December 2017, available at en.mfa.ir/index.aspx?fkeyid=\&siteid=3\&pageid=1997\&newsview $=489778$, ‘ . Palestine of their basic rights to establish an independent state for their own with al-Quds as its capital'.

${ }^{106}$ Uruguay, UN Doc. S/PV.8128 (2017); Holy See, UNGA Res. A/ES-10/PV.37 (2017). See also, Senegal, UN Doc. S/ PV.8139 (2017).

${ }^{107}$ Pakistan, UN Doc. S/PV 8244 (2018), ‘ . . peace between Israel and the Palestinian people and other Arab and Muslim peoples can only be built through a two-State solution. An illusory one State will perpetuate occupation and conflict and provide neither peace nor security'.

${ }^{108}$ Interestingly, some of the states which made reference to a Palestinian State with East Jerusalem as its capital do not acknowledge at the same time the need for a two-state solution. This is the position, for instance, North Korea, a state that has not recognized Israel. North Korea, UNGA Res. A/ES-10/PV.37 (2017).

${ }^{109}$ NAM, UN Doc. S/PV. 8167 (2018).

${ }^{110}$ China, UN Doc. S/PV.8128 (2017).

${ }^{111}$ Malta, UN Doc. S/PV 8244 (2018).
} 
Israel-Palestine conflict, ${ }^{112}$ while South Africa talks about an 'international legal framework' within which negotiations between the parties shall take place. ${ }^{113}$ The content of this consensus is often shaped around the main peace plans, such as the Arab Peace Initiative of 2002 or the Quartet Road Map. ${ }^{114}$ These documents are also recalled as the bases for peace negotiation by states that do not expressly mention the existence of an international consensus. ${ }^{115}$

Much more controversial is the question of borders. Whereas the exercise of the Palestinians' right to self-determination through the establishment of an independent state is not put into question, the precise borders of such a state are not always clearly identified. After the relocation of the US embassy, statements refer to the final borders of the Palestinian state using slightly different phrases. We identified the following different wordings referring to the 'borders' of 4 June 1967: 'within the borders', 'on the borders', 'based on the borders', 'along the borders', and 'on the basis of the borders'. We believe that the first two express less flexibility compared to the last three, although, admittedly, there is room for interpretation, especially in the case of the second. We classified the statements accordingly: 1 and 2 as strict, and 3, 4, 5 as flexible, although, at times, some contradictions among statements by the same state emerged. ${ }^{116}$

Essentially, flexibility with regard to the borders takes two forms: whereas the language used by some states makes reference to the 1967 lines as a mere parameter for the negotiation, ${ }^{117}$ other statements identify precisely the 1967 lines as the future borders of the Palestinian state, but at the same time underline that they can be altered only through negotiation. ${ }^{118}$ Some states quoted verbatim the text of Resolution 2334, according to which the UNSC 'will not recognize any changes to the pre-1967 lines, including with regard to Jerusalem, other than those agreed by the parties through negotiations.' ${ }^{119}$

Overall, the practice gives evidence that the majority of states agree on the fact that Palestine's territory shall be the West Bank and the Gaza Strip, considered as a single territorial unit. This

\footnotetext{
${ }^{112}$ Japan, UN Doc. S/PV 8244 (2018); Luxembourg, Statement by Minister of Foreign and European Affairs of Luxembourg Jean Asselborn after the announcement by the President of the United States regarding Jerusalem, 7 December 2017, available at gouvernement.lu/en/actualites/toutes_actualites/communiques/2017/12-decembre/07-asselborn-jerusalem; The Netherlands, UN Doc. S/PV 8244 (2018).

${ }^{113}$ South Africa, UN Doc. S/PV 8244 (2018).

${ }^{114}$ Venezuela referred to 'the long-standing terms of reference of a peace settlement endorsed by the international community, pursuant to the relevant United Nations resolutions, the Madrid principles, including the land-for-peace principle, the Arab Peace Initiative and the Quartet road map'. Venezuela, UNGA Res. A/ES-10/PV.37 (2017). See also, South Africa, UN Doc. S/PV 8244 (2018).

${ }^{115}$ Yemen, UNGA Res. A/ES-10/PV.37 (2017).

${ }^{116}$ Morocco, for instance, speaks both of a 'State of Palestine with East Jerusalem as its capital, based on the 4 June 1967 borders' (emphasis added) and of 'an independent Palestinian State with East Jerusalem as its capital, within the 4 June 1967 borders' (emphasis added) (Morocco: UN Doc. S/PV 8244 (2018)), or as Syria that calls for the withdrawal of Israel from the territories occupied in 1967 including Al Quds (i.e,. East Jerusalem), but at the same time when approaching the issue of the borders of the Palestinian State calls for Jerusalem as its capital without limiting its statement to the Eastern part of the city occupied in 1967, thus creating some ambiguities as to the perimeter of the Palestinian State (Syria, UNGA Res. A/ES-10/ PV.37 (2017); UN Doc. S/PV 8244 (2018)).

${ }^{117}$ Brazil expressed 'full support for implementing a two-State solution to the Israeli-Palestinian conflict, with Palestine and Israel living side by side in peace and security, within mutually agreed and internationally recognized borders based on the 1967 borders ...' (Brazil: UN Doc. S/PV 8244 (2018)); Poland argued ' . . we would like this issue to be resolved by bilateral negotiations between Israel and the Palestinians, we are in favor of keeping the border set in 1967 ... with certain corrections of course, forced by reality'. See 'EU foreign ministers meet on Monday to discuss the situation in the Middle East and other issues', 11 December 2017, supra note 69.

${ }^{118}$ Belgium argued '[o]ur country will not recognise any change to the borders of 1967 , including with regard to Jerusalem, unless these changes are agreed on by both parties', Violence in the Gaza Strip - reaction Charles Michel and Didier Reynders, 15 May 2018, available at diplomatie.belgium.be/en/newsroom/news/2018/violence_gaza_strip_reaction_charles_michel_ and_didier_reynders. See also, Argentina, Res. A/ES-10/PV.37 (2017); Sweden, United Nations Security Council Briefing on 'The situation in the Middle East including the Palestinian question', 8 December 2017, available at www.government. se/statements/2017/12/ny-sida2/.

${ }^{119}$ Sweden's Statement, ibid.
} 
territorial unit represents the basis for any negotiation and reflects the geographical identification of the Palestinian State in international agreements stipulated by Palestine, ${ }^{120}$ the practice of the General Assembly, ${ }^{121}$ and the framework of the main peace plans. ${ }^{122}$ An element of uncertainty, however, is the room left to territorial swaps between the parties. As will be seen in the ensuing sub-section, the conditions under which the final negotiations should take place are also open to debate.

\subsubsection{Procedural issues on the exercise of self-determination}

Direct reference to the principle of self-determination, as the basis for the final settlement of the Israeli-Palestinian question, is made by NAM and OIC (altogether 125 states) and by Poland. In addition, the almost universal acceptance of the two-state solution in the examined practice clearly shows that the right of the Palestinian people to establish an independent state is by no means put into question. As often happens with self-determination, however, the problem does not lie in the objective to be achieved but rather in the procedure to be implemented. ${ }^{123}$

There are two main procedural issues related to the exercise of the right to self-determination emerging from the examined statements.

The first issue revolves around the degree of engagement of the international community in the negotiations for the final settlement. There are two main views in this respect: whereas some states call for the involvement of the international community in a multilateral management of the crisis, ${ }^{124}$ at the opposite end of the spectrum, other states envisage a bilateral direct negotiation. ${ }^{125}$ Within the first group, the proposal of Palestine for an international peace conference to resume peace talks stresses that the US is disqualified as a mediator and highlights the need to adopt a truly multilateral method by getting new actors involved in the mediation effort. ${ }^{126}$ Along the same lines, South Africa speaks of a 'commitment to multilateralism in order to secure a sustainable solution', ${ }^{127}$ while Nigeria highlights 'the cogency of multilateral diplomacy, and reiterate[s] that there is no substitute to an agreed multilateral approach for addressing the Israeli-Palestinian

\footnotetext{
${ }^{120}$ See EC-Palestine Association Agreement (signed in 1997 and entered into force in 1997); Turkey-Palestine Interim FTA (signed in 2004 and entered into force in 2005); EFTA-Palestine Interim Agreement (signed in 1998 and entered into force in 1999) referring to the 'West Bank' and the 'Gaza Strip' and Germany-Palestine Liberation Organization BIT (signed in 2000 and entered into force in 2008) referring to 'the territory under the self-administration of the Palestinian Authority'.

${ }^{121}$ UNGA, Res. 67/19, UN Doc. A/RES/67/19 (2012), para. 1; UN Doc. A/RES/58/292 (2004), para. 2; UN Doc. A/RES/43/ 177 (1988), para. 2.

${ }^{122}$ The Arab Peace Initiative (28 March 2002) provides for a ' . . f full Israeli withdrawal from all the territories occupied since 1967, including the Syrian Golan Heights to the lines of 4 June 1967 as well as the remaining occupied Lebanese territories in the south of Lebanon', available at www.europarl.europa.eu/meetdocs/2009_2014/documents/empa/dv/1_arabinitiative-beirut_/1_arab-initiative-beirut_en.pdf.

${ }^{123} \mathrm{~A}$. Tancredi, 'Le droit à l'autodétermination du peuple palestinien', in T. Garcia (ed.), La Palestine: d'un État non membre de l'Organisation des Nations Unies à un État souverain? (2016).

${ }^{124}$ Venezuela and NAM, UN Doc. S/PV 8244 (2018); Nigeria, UN Doc. S/PV 8244 (2018); South Africa, South Africa's position on the unilateral decision taken by the United States to recognise Jerusalem as the capital of Israel which undermines Middle East Peace Process, 7 December 2017, available at www.dirco.gov.za/docs/2017/isra1208.htm.

${ }^{125}$ Japan, Japan-Palestine Summit Overview, 1 May 2018, available at www.mofa.go.jp/me_a/mel/palestine/ page1e_000224.html; Thailand, Thailand's Statement on the Status of Jerusalem and the Situation between Israel and Palestine, 9 December 2018, available at www.mfa.go.th/main/en/news3/6886/84503-Thailand\%27s-Statement-on-theStatus-of-Jerusal.html; Peru, UN Doc. S/PV 8256 (2018); Paraguay, UN Doc. A/ES-10/PV.37 (2017); Mexico, UN Doc. A/ES-10/PV.37 (2017); Bulgaria, Opinion of the Ministry of Foreign Affairs, 15 May 2018, available at www.mfa.bg/en/ news/18220; Latvia, Foreign Minister Rinkēvičs, supra note 66.

${ }^{126}$ According to Palestine, 'only a collective effort can resolve the prolonged conflict' and 'all must do their part' because 'one party cannot continue to monopolize the peace process, and especially not one that acts with a bias in favor of the occupying Power at the expense of the law and rights of the occupied people'. See Palestine, UN Doc. S/PV.8128 (2017).

${ }^{127}$ South Africa's Position, supra note 124.
} 
conundrum ... ${ }^{128}$ Within states emphasizing the need for bilateral talks, ${ }^{129}$ the US adopts an extreme position according to which any solution to the Israeli-Palestinian conflict would be acceptable if agreed upon by the two parties involved, with no indication of any internationally agreed parameter for the settlement of the issue. ${ }^{130}$ In this regard, it is perhaps understandable that some states mildly criticised the US position expressing their hope that 'the United States can [still?] lend their full support to the two-state solution'. ${ }^{131}$

The second procedural issue touches upon the crucial problem of withdrawal from the Occupied Territories. Whereas a substantive number of states (126), mostly represented by the NAM countries, considers Israel's withdrawal from the Palestinian territories as one of the conditions to achieve peace and, among them, some take the view that such withdrawal should take place urgently or immediately as a precondition to start negotiations, ${ }^{132}$ other states, mostly represented by the EU, do not mention the need for an Israeli withdrawal that would seem to be treated as a mere consequence of the negotiation process (53 states). It is worth observing that most of the states considering Israel's withdrawal as one of the conditions for the peace talks have referred to the Arab Peace Initiative of 2002 as a parameter for the settlement of the conflict. ${ }^{133}$ Indeed, the Arab Peace Initiative calls for 'full Israeli withdrawal from all the territories occupied since 1967 ...' and the 'establishment of an independent and sovereign Palestinian State on the Palestinian territories occupied since 4 June 1967 in the West Bank and Gaza Strip with East Jerusalem as its capital'. ${ }^{134}$ Initiating the peace talks after having restored Palestinian control over the West Bank and the Gaza Strip would mean allowing Palestine a seat at the negotiating table as a peer of Israel to discuss the final settlement of Jerusalem and the Middle East issue more broadly. On the contrary if, as many states (40) seem to envisage, Israel's withdrawal represents only a possible outcome of peace talks, Palestine would have to start negotiations with the Occupying Power with little, if no chance, to be heard.

\section{Concluding remarks}

The two research questions discussed above are intrinsically intertwined. The answer that states provide to the first (compliance with the duty of non-recognition) inevitably impacts on the second (the prospects for peace) and on the capacity of the Palestinian people to exercise their right to self-determination. State practice shows that a general duty not to recognize the unlawful acquisition of territory is widely accepted as a rule notwithstanding a great variety of positions as to its legal basis and conceptualization. As long as the majority of states believe that the situation existing on the ground in consequence of Israeli (or US) violations of peremptory norms shall not

\footnotetext{
${ }^{128}$ Nigeria, UN Doc. S/PV 8244 (2018).

${ }^{129}$ Poland, see Poland's Statement, supra note 69; Georgia, Statement by the Ministry of Foreign Affairs of Georgia, 7 December 2017, available at mfa.gov.ge/News/\%E2\%80\%8Bsaqartvelos-sagareo-saqmeta-saministros-ganck-(2).aspx; Lithuania, 'Statement on the UNGA Resolution on Status of Jerusalem', 22 December 2017, available at www.urm.lt/ default/en/news/statement-on-the-unga-resolution-on-status-of-jerusalem; Kazakhstan, UN Doc. S/PV.8128 (2017).

${ }^{130}$ The US takes the stance that it 'remains deeply committed to helping facilitate a peace agreement that is acceptable to both sides' and it 'would support a two-state solution if agreed to by both sides' (emphasis added). Statement by President Trump on Jerusalem, supra note 54. See also, Georgia, ibid.

${ }^{131}$ Sweden's Statement, supra note 118; Luxembourg's Statement, supra note 112.

${ }^{132}$ Saudi Arabia, UN Doc. S/PV 8244 (2018); Venezuela and NAM, UN Doc. S/PV. 8167 (2018); Kuwait, UN Doc. S/PV 8256 (2018).

${ }^{133}$ A representative example is Kuwait: '.. in order to achieve the long-desired peace, we must start by putting an end to the Israeli occupation, whose fifty-first anniversary is coming up in a few days. That should be based on the resolutions of international legitimacy, the principle of land for peace, the road map and the Arab Peace Initiative, adopted by all Arab States at the 2002 Beirut summit. It should also be based on the withdrawal of Israel from all Palestinian, Syrian and Lebanese territories to the June 1967 borders ...', UN Doc. S/PV 8256 (2018).

${ }^{134}$ The Arab Peace Initiative, 28 March 2002, supra note 122.
} 
be recognized, the implementation of the two-state solution remains viable. As has been seen, however, there is no clarity on the procedure to be adopted.

In practical terms, the US decision to move its embassy to Jerusalem, despite the broad caveat concerning the scope of Israel's sovereignty, has the effect of weakening the prospects for peace and, especially, the role that the Palestinian people can play in shaping such a peace. This is particularly true considering that, at the time of writing, there are no credible diplomatic initiatives and that, according to the US, any solution to the Israeli-Palestinian conflict would be acceptable if agreed upon by the two parties involved. This attitude towards the bi-lateralization of the crisis, despite the current inequality of arms between the parties deriving from the situation on the ground, does not favour the achievement of a just and lasting peace. The almost unanimous reaction of states (164) to the US decision and their almost unanimous commitment to the two-state option (166) will remain dead letter if the solution of the crisis is left to a future bilateral agreement. The hopes of a settlement with two states living in peace within secure borders depend on the adoption of a new multilateral initiative safeguarding the interests of both parties, including the party that is called to seat at the negotiating table as an occupied territory.

Cite this article: Pertile M and Faccio S (2020). What we talk about when we talk about Jerusalem: The duty of nonrecognition and the prospects for peace after the US embassy's relocation to the Holy City. Leiden Journal of International Law 33, 621-647. https://doi.org/10.1017/S0922156520000229 